\title{
G-Protein-Coupled Estrogen Receptor 1 Is Anatomically Positioned to Modulate Synaptic Plasticity in the Mouse Hippocampus
}

\author{
Elizabeth M. Waters, ${ }^{1}$ Louisa I. Thompson, ${ }^{1,2}$ (P) Parth Patel, ${ }^{2}$ (D)Andreina D. Gonzales, ${ }^{2}$ Hector (Zhiyu) Ye, ${ }^{2}$

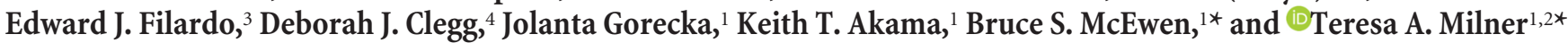 \\ ${ }^{1}$ Harold and Margaret Milliken Hatch Laboratory of Neuroendocrinology, The Rockefeller University, New York, New York 10065, ${ }^{2}$ Brain and Mind \\ Research Institute, Weill Cornell Medical College, New York, New York 10065, ${ }^{3}$ Department of Medicine, Brown University, Providence, Rhode Island \\ 02903, and ${ }^{4}$ Department of Internal Medicine, University of Texas Southwestern Medical Center at Dallas, Dallas, Texas 75390
}

Both estrous cycle and sex affect the numbers and types of neuronal and glial profiles containing the classical estrogen receptors $\alpha$ and $\beta$, and synaptic levels in the rodent dorsal hippocampus. Here, we examined whether the membrane estrogen receptor, G-protein-coupled estrogen receptor 1 (GPER1), is anatomically positioned in the dorsal hippocampus of mice to regulate synaptic plasticity. By light microscopy, GPER1-immunoreactivity (IR) was most noticeable in the pyramidal cell layer and interspersed interneurons, especially those in the hilus of the dentate gyrus. Diffuse GPER1-IR was found in all lamina but was most dense in stratum lucidum of CA3. Ultrastructural analysis revealed discrete extranuclear GPER1-IR affiliated with the plasma membrane and endoplasmic reticulum of neuronal perikarya and dendritic shafts, synaptic specializations in dendritic spines, and clusters of vesicles in axon terminals. Moreover, GPER1-IR was found in unmyelinated axons and glial profiles. Overall, the types and amounts of GPER1-labeled profiles were similar between males and females; however, in females elevated estrogen levels generally increased axonal labeling. Some estradiol-induced changes observed in previous studies were replicated by the GPER agonist G1: G1 increased PSD95-IR in strata oriens, lucidum, and radiatum of $\mathrm{CA} 3$ in ovariectomized mice $6 \mathrm{~h}$ after administration. In contrast, estradiol but not G1 increased Akt phosphorylation levels. Instead, GPER 1 actions in the synapse may be due to interactions with synaptic scaffolding proteins, such as SAP97. These results suggest that although estrogen's actions via GPER1 may converge on the same synaptic elements, different pathways are used to achieve these actions.

Key words: estrogen; estrogen receptors; estrous cycle; G-protein-coupled receptors; sex differences

\section{Introduction}

Estrogens in the brain can act nongenomically on extranuclear receptors affiliated with the plasma membrane or membranous organelles to rapidly activate signaling pathways (Kelly and Levin, 2001; Spencer et al., 2008b), as well as genomically where they can alter synapse density, synaptic transmission, and behavior (for review, see Spencer et al., 2008b). Historically, the classical estrogen receptors (ERs) ER $\alpha$ and $\mathrm{ER} \beta$ have been implicated in a large number of brain responses to estrogen due to their ability

\footnotetext{
Received March 17, 2014; revised Dec. 1, 2014; accepted Dec. 4, 2014.

Author contributions: E.M.W., K.T.A., B.S.M., and T.A.M. designed research; E.M.W., L.I.T., P.P., A.G., H.Z.Y., J.G., K.T.A., and T.A.M. performed research; E.J.F. and D.C. contributed unpublished reagents/analytic tools; E.M.W., L.I.T., J.G., K.T.A., and T.A.M. analyzed data; E.M.W. and T.A.M. wrote the paper.

This work was supported by NIH Grants NS007080 and AG16765 (B.S.M.), DA08259, HL096571 and HL098351 (T.A.M.), DK07313 and AG039850 (E.M.W., T.A.M.), DK088761 (D.C.). We thank Sanoara Mazid for help with figure preparation, and Mariana Dodos and Tracey Van Kempen for help with statistical analysis.

The authors declare no competing financial interests.

*B.S.M. and T.A.M. contributed equally to this work.

Correspondence should be addressed to Dr Elizabeth Waters, Harold and Margaret Milliken Hatch Laboratory of Neuroendocrinology, The Rockefeller University, 1230 York Avenue, New York, NY 10065. E-mail: ewaters@rockfeller.edu.

DOI:10.1523/JNEUROSCI.1298-14.2015

Copyright $\odot 2015$ the authors $\quad 0270-6474 / 15 / 352384-14 \$ 15.00 / 0$
}

to initiate both genomic and nongenomic actions (Razandi et al., 1999; Hammes and Levin, 2007). Continuing work to seek out novel estrogen-sensitive proteins identified G-protein-coupled estrogen receptor 1(GPER1), a seven-transmembrane G-protein-coupled receptor that binds estrogens with high affinity (Revankar et al., 2005; Thomas et al., 2005). GPER1 was shown to act independently of $\operatorname{ER} \alpha$ and $\operatorname{ER} \beta$ but likely stimulates the same secondmessenger pathways and has genomic actions (Maggiolini et al., 2004). Thus, the effects of estrogens in the brain likely depend on the relative expression and cellular locations of multiple ERs.

In the rat hippocampus, $\mathrm{ER} \alpha$ and $\mathrm{ER} \beta$ are differentially located at nuclear and extranuclear sites. Nuclear ER $\alpha$-immunoreactivity (IR) is found only in inhibitory interneurons (Weiland et al., 1997; Milner et al., 2001; Nakamura and McEwen, 2005; McEwen and Milner, 2007), whereas nuclear ER $\beta$-labeling is not detected in either principal cells or interneurons (Milner et al., 2005; Waters et al., 2008). In contrast, extranuclear $\mathrm{ER} \alpha$ and $\mathrm{ER} \beta$ are widespread in the hippocampus of rats and mice (Milner et al., 2005; Waters et al., 2008; Mitterling et al., 2010). Despite the relative paucity of nuclear ERs, estrogen regulates synaptic plasticity in the dorsal rat and mouse hippocampus (Woolley et al., 1996; Woolley, 1998; Li et al., 2004) and increases the expression of 
synaptic proteins, particularly PSD-95, however, these changes are mostly limited to CA1 in rats whereas they occur in many hippocampal regions in mice (Brake et al., 2001; Spencer et al., 2008a; Waters et al., 2009; Spencer-Segal et al., 2012). In mice, loss of extranuclear $\operatorname{ER} \alpha$ and $\operatorname{ER} \beta$ reduces the estrogen-induced increase in PSD-95 expression and estrogen mediated signaling but does not eliminate it (Spencer-Segal et al., 2012). Estrogens also regulate the activity of glutamatergic NMDA receptors (Woolley and McEwen, 1994; Woolley et al., 1997) through changes in the synaptic localization of subunit NR2B (Snyder et al., 2011). GPER1 activation also regulates NR2B and may contribute to estrogen's beneficial actions including neuroprotection (Kosaka et al., 2012; Bourque et al., 2013; Liu and Zhao, 2013). Reports of GPER1 actions on hippocampal-dependent memory, location with dendritic spines, and interactions with PSD-95 in rats (Hammond and Gibbs, 2011; Hammond et al., 2011; Akama et al., 2013) support a larger role for GPER 1 in the modulation of estrogen-mediated plasticity and in sex differences within the hippocampus.

To address this hypothesis, we determined the ultrastructural localization of GPER1 in the hippocampus of male and female mice at different stages of the estrous cycle. We also examined whether GPER1 activation replicates estrogen's effects in the hippocampus.

\section{Materials and Methods}

Animals. All experiments were approved by the Rockefeller University Institutional Animal Care and Use Committee and were conducted in accordance with the NIH Guide for the Care and Use of Laboratory Animals. Adult female $(n=43)$ and male $(n=6)$ C57BL/6 mice (aged between 2 and 3 months) from The Jackson Laboratory were used. All mice were housed in Thoren cages (Thoren Caging Systems) with $12 \mathrm{~h}$ light/dark cycles (lights on 0:600-18:00). Only females with regular estrous cycles over a 3 week period, as determined by vaginal smear cytology (Turner and Bagnara, 1971) were used in the GPER1 localization experiment. Moreover, the mice used in the electron microscopic experiments were the same as those used in our previous studies (Mitterling et al., 2010; Spencer-Segal et al., 2011).

Mice carrying a GPER1-null mutation (male; $N=6$ ) were generated by targeted disruption of the GPER1 gene with a Neo cassette as previously described (Wang et al., 2008). The Neo cassette (clone T142) contained both a $1.2 \mathrm{~kb}$ fragment from the EcoR1 site of the second kpn 1 site (short arm construct) and a $4 \mathrm{~kb}$ fragment from BamHl to Xhol (long arm construct) of the mouse GPER1 gene. Although this Neo cassette knocks out GPER1 functionality, it does not totally eliminate the production of GPER1 protein fragments. The mice were maintained on a C57BL/6J and 129SvEvTac background and were $\sim 3$-months-old at the time of euthanasia (Ford et al., 2011).

Wild-type C57BL6 female mice were ovariectomized under isoflurane anesthesia. One week after surgery, the mice received subcutaneous injections of vehicle ( $50 \mu \mathrm{l}$, sesame oil with $0.1 \%$ DMSO), $5 \mu$ g estradiol benzoate (EB), or $5 \mu \mathrm{g} \mathrm{G1}$, a GPER1 agonist. The mice were killed $6 \mathrm{~h}$ or $30 \mathrm{~min}$ after the injection. Previous studies showed that PSD-95 and pAKT levels in mouse hippocampus are elevated $6 \mathrm{~h}$ following estradiol administration (Spencer-Segal et al., 2012).

\section{Immunocytochemistry}

Antibodies. A rabbit polyclonal antibody generated against a synthetic peptide, CAVIPDSTEQSDVRFSSAV (Multiple Peptide Systems), derived from the C-terminus of the deduced sequence of the human GPER1 polypeptide was used in this study (Filardo et al., 2000). On Western blots, this antibody specifically recognizes a $38 \mathrm{kDa}$ band that corresponds to the mature 351 aa GPER1 polypeptide and does not recognize either ER $\alpha$ or $\beta$ (Filardo et al., 2000). In $4 \%$ paraformaldehyde perfusion fixed rat brain tissue, immunoreactivity was greatly reduced when the antibody was preadsorbed with $10 \mathrm{mg} / \mathrm{ml}$ purified C-terminal peptide (Hammond et al., 2011). To additionally test the specificity of the GPER1 antibody in mice using our labeling conditions, two additional controls were conducted. First, a preadsorption control was performed in acrolein/paraformaldehyde fixed hippocampal sections from wild-type C57BL6 mice. For this, $2 \mathrm{ml}$ of the working dilution of the antiserum (1:2000) was divided into two scintillation vials. Forty micrograms of the antigenic peptide in $50 \mu \mathrm{l}$ saline was added to one vial and $50 \mu \mathrm{l}$ saline was added to the other vial, and the vials were incubated overnight at $4^{\circ} \mathrm{C}$ on a shaker table. The following day, the solutions were spun at 10,000 rpm for 10 min on a microfuge and the supernatant was collected and used for peroxidase immunocytochemistry as described. Second, hippocampal tissue from acrolein/paraformaldehyde fixed GPER1 knock-out mice and controls was processed for GPER1 peroxidase immunolabeling as described in Immunolabeling.

A monoclonal mouse anti-PSD-95 (1:5000) was purchased from Sigma-Aldrich. Western blot confirmed the specificity of this antibody, where it recognized the same double band as an affinity-purified rabbit PSD-95 antiserum (Kornau et al., 1995).

Preparation of tissue. Mice were deeply anesthetized with sodium pentobarbital (150 mg/kg, i.p.) and were perfused sequentially through the ascending aorta with: $(1) \sim 5 \mathrm{ml}$ saline $(0.9 \%)$ containing 1000 units of heparin, and (2) $30 \mathrm{ml}$ of $3.75 \%$ acrolein and $2 \%$ paraformaldehyde in $0.1 \mathrm{~m}$ phosphate buffer, pH 7.4 (Milner et al., 2011). Following removal from the skull, the brains were postfixed in $2 \%$ acrolein and $2 \%$ paraformaldehyde in PB for $30 \mathrm{~min}$. The brains were transferred to PB, cut into $5 \mathrm{~mm}$ coronal blocks and then cut $(40 \mu \mathrm{m}$ thick) on a vibrating microtome (Vibratome, Leica) and collected into PB. Sections were stored at $-20^{\circ} \mathrm{C}$ in cryoprotectant ( $30 \%$ sucrose, $30 \%$ ethylene glycol in $\mathrm{PB}$ ) until immunocytochemical processing. To minimize differences in immunocytochemical labeling, sections from each mouse were coded with hole punches and pooled into sets so that they could be processed together for all steps (Pierce et al., 1999; Spencer et al., 2008a). For the electron microscopic experiments, each set $(N=6)$ contained a male, a diestrous female, a proestrous female, and an estrous female. For the PSD-95 experiments, each set $(N=5)$ contained an ovariectomized female administered oil, estradiol, or G1.

Immunolabeling. Free-floating sections were processed for immunoperoxidase using a modification of the avidin-biotin complex protocol (Milner et al., 2011). Briefly, hippocampal sections were rinsed in PB to remove cryoprotectant and then incubated in $1 \%$ sodium borohydride in $\mathrm{PB}$ for $30 \mathrm{~min}$ to remove active aldehydes. Sections were washed in 8-10 changes of $\mathrm{PB}$ until all the gaseous bubbles disappeared and then placed in $0.1 \mathrm{~m}$ Tris-buffered saline (TS), $\mathrm{pH}$ 7.6. Sections were then incubated sequentially in: (1) $0.5 \%$ bovine serum albumin (BSA) in TS; (2) primary antisera in 0.1\% BSA in TS (GPER1, 1:3000; PSD95,1:2000) for $1 \mathrm{~d}$ at room temperature $\left(\sim 23^{\circ} \mathrm{C}\right)$, followed by $3-4 \mathrm{~d}$ cold $\left(\sim 4^{\circ} \mathrm{C}\right)$; (3) $1: 400$ of biotinylated anti-rabbit IgG (GPER1) or anti-mouse IgG (PSD95; both from Jackson ImmunoResearch), $30 \mathrm{~min}$; (4) 1:100 peroxidase-avidin complex (Vectastain Elite Kit), $30 \mathrm{~min}$; and (5) 3,3'-diaminobenzidine (DAB; Sigma-Aldrich) and $\mathrm{H}_{2} \mathrm{O}_{2}$ in TS, 6-8 min. All incubations were separated by washes in TS.

Some sections were processed for GPER1-IR using the silver enhanced immunogold (SIG) technique (Milner et al., 2011). For this, sections were processed up to the secondary antibody incubation step as described for immunoperoxidase except that the primary antibody was diluted 1:2000. The sections then were incubated in a 1:50 dilution of goat anti-rabbit IgG conjugated to $1 \mathrm{~nm}$ gold particles (1:50, Electron Microscopy Sciences (EMS)) in $0.08 \%$ BSA and $0.001 \%$ gelatin in $0.01 \mathrm{M}$ PBS, $\mathrm{pH} 7.4$, for $2 \mathrm{~h}$ at room temperature. Next, the sections were rinsed in PBS, postfixed in $2 \%$ glutaraldehyde for $10 \mathrm{~min}$ and rinsed in PBS followed by $0.2 \mathrm{M}$ sodium citrate buffer, $\mathrm{pH}$ 7.4. The gold particles were enhanced by incubation of a silver solution (EMS) for 5-7 min. The sections were then prepared for electron microscopy.

For light microscopy, sections were rinsed in $\mathrm{PB}$ and mounted onto gelatin-coated glass slides. Sections then were dehydrated through a graded alcohol series to xylene and coverslipped with DPX mounting media (Sigma-Aldrich).

For electron microscopy, sections were postfixed for $1 \mathrm{~h}$ in $2 \%$ osmium tetroxide in $\mathrm{PB}$, dehydrated through a series of alcohols and propylene oxide, and embedded in EMBed 812 (EMS) between two sheets of 
plastic (Milner et al., 2011). Sections from the midseptotemporal level of the dorsal hippocampus (between AP -2.10 and -2.40 from bregma; Hof et al., 2000) were selected, mounted on EMBed chucks and trimmed to $1-1.5 \mathrm{~mm}$ wide trapezoids. Ultrathin sections (70 nm thick) within $0.1-0.2 \mu \mathrm{m}$ to the tissueplastic interface were cut on a Leica UTC ultratome, collected on grids, and counterstained with uranyl acetate and Reynold's lead citrate. Final preparations were analyzed on a FEI Tecnai Biotwin transmission electron microscope and images were acquired with a digital camera system (v3.2, Advanced Microscopy Techniques). For figures, digital images were adjusted for levels, brightness, contrast, and sharpness (using the unsharp mask function) in Adobe PhotoShop. Final figures were assembled in PowerPoint.

LM quantitative analysis. Quantitative densitometry was performed as previously described (Torres-Reveron et al., 2006, 2008; Pierce et al., 2014). Tissue from control and experimental animals was processed together in the same crucibles. Sections from each animal were selected from the dorsal hippocampus $(-1.60$ to -2.50 from bregma;Hof et al., 2000) and matched sections were selected for processing with each antibody. A single hippocampus from each animal with the best morphology and consistent immunoperoxidase labeling was included in the analysis. Slides were coded for blind analysis. Images of regions-of-interest were captured with a $10 \times$ objective on a Nikon Eclipse 80i microscope using a Dage MTI CCD-72 camera and control unit (with preset gain and black levels) and MicroComputer Imaging Device software. To compensate for uneven illumination across the field, blank fields taken from a slide lacking tissue were subtracted. For each captured image, average pixel densities (from 256 gray levels) then were determined using NIH ImageJ software. To compensate for background labeling and control for variations in the overall illumination levels between images, the average pixel density for three regions lacking labeling was subtracted from all density measurements made on a particular image. The accuracy of the hardware and software was tested by calculating pixel densities for captured images of neutral density gelatin filters with defined transmittances ranging from $1 \%$ to $80 \%$ (Eastman Kodak). These tests showed a strong linear correlation between average pixel densities and actual transmittance values (Pierce et al., 2014).

A one-way ANOVA analysis and Tukey-Kramer post hoc tests (Jmp 11, SAS) were used to determine group differences by treatment. Significance was considered $>0.05$. Graphs were prepared with GraphPad Prism 5.2.

Light microscopic immunoperoxidase-labeled sections were photographed on a Nikon Eclipse 80i microscope equipped with bright-field and DIC optics and a Micropublisher digital camera (Q-Iimaging). In Figure 1, the same camera settings and light levels were used in tissue photographed from the wild-type and GPER1 knock-out mice. Levels, contrast, and brightness were adjusted for each image in Adobe Photoshop and final figures assembled in PowerPoint.

EM analysis. Quantitation of GPER1 profiles at the ultrastructural level was performed as previously described (Mitterling et al., 2010; Eagleson et al., 2013). For this, electron microscopic examination was performed on one hippocampal GPER1-peroxidase-labeled section per animal from each group for four sets of mice (e.g., 3 proestrous, 3 diestrous, or 3 estrous females or 3 males; $N=12$ ). From each section, the CA1 region, CA3 region, and dentate gyrus were examined. In the CA1, stratum radiatum was divided into a proximal field (within $70 \mu \mathrm{m}$ from stratum pyramidale) and a distal field ( $>70 \mu \mathrm{m}$ from stratum pyramidale and closer to near stratum lacunosum-moleculare). In each section, 10 random, but nonoverlapping, micrographs ( $36 \mu \mathrm{m}^{2} /$ micrograph $)$ per lamina per brain region were taken. To ensure optimal labeling and to allow unbiased comparisons between groups, only tissue sections containing the tissue-plastic interface were selected (Milner et al., 2011).

Immunolabeled profiles were classified using the nomenclature of $\mathrm{Pe}$ ters et al. (1991). Dendritic shafts contained regular microtubular arrays and were usually postsynaptic to axon terminal profiles. Dendritic spines also were usually postsynaptic to axon terminal profiles and sometimes contained a spine apparatus. Axon terminal profiles had numerous small synaptic vesicles and had a cross-sectional diameter $>0.2 \mu \mathrm{m}$. Unmyelinated axons were profiles smaller than $0.15 \mu \mathrm{m}$ that contained a few small synaptic vesicles and lacked a synaptic junction in the plane of section. Sometimes peroxidase immunoreactivity obscured microtubules in unmyelinated axons. In these cases, the profiles were considered "axonal" if they had similar morphological features to axon profiles iden- 
tified previously with markers exclusively found in axons and terminals (i.e., tyrosine hydroxylase and enkephalin; Milner and Bacon, 1989; Torres-Reveron et al., 2008). In particular, unmyelinated axons did not conform to the boundaries of the neuropil as glial processes do. Astrocytic profiles were distinguished by the presence of glial filaments, by the absence of microtubules, and/or by their tendency to conform irregularly to the boundaries of surrounding profiles. "Unknown profiles" were those that contained immunoperoxidase reaction product but could not be definitively placed in one of the above categories.

Data comparing sex and estrous cycle phase were analyzed three ways. First, the relative distribution of each type of profile per lamina regardless of cycle/sex was calculated. For this, the mean and SEM for each type of profile in each lamina was calculated by combining data from all 12 animals; these values are shown in Table 2. Second, all profiles from each animal were pooled by type (dendritic shafts, dendritic spines, terminals, axons, and glia) and compared across groups using a one-way ANOVA and Tukey-Kramer post hoc tests (Jmp 11). Data for each profile type are presented in Table 3 as a total number of profiles per group. Third, a lamina analysis limited to the CA1 stratum radiatum (distal) and the CA3 stratum lucidum was performed because of their known sensitivity to estrogens (McEwen and Milner, 2007; Torres-Reveron et al., 2008, 2009) and because ERs, progestin receptors, and phosphorylated TrkB-labeled axons fluctuate across the estrous cycle in these regions in the same mice used for the present studies (Mitterling et al., 2010; Spencer-Segal et al., 2011). For this, profile type and group were compared by one-way ANOVA followed by a Tukey-Kramer post hoc test. Data comparing numbers of GPER1-labeled profiles in wild-type vs GPER1 knock-out mice also were compared using a Student's $t$ test. Significance was considered $p<0.05$.

Synaptosomes. Crude synaptosomal lysates were prepared from adult female mouse hippocampi dissected and placed immediately in cold homogenization buffer A (0.32 м sucrose, 20 mM HEPES, pH 7.4, $1 \mathrm{~mm}$ EDTA, $1.25 \mathrm{~mm} \mathrm{NaF}, 1 \mathrm{~mm} \mathrm{NaVO}_{3}$ ) with freshly added protease inhibitor cocktail (Sigma-Aldrich; Li et al., 2010). Hippocampi from three individual animals were homogenized in $300 \mu \mathrm{l}$ of ice-cold buffer A using a rotary microfuge pestle. Lysates were cleared of debris and nuclei by centrifugation at $2800 \mathrm{rpm}$ for $10 \mathrm{~min}$ at $4^{\circ} \mathrm{C}$. The supernatant was collected and recentrifuged at 12,000 rpm for $10 \mathrm{~min}$ at $4^{\circ} \mathrm{C}$. The pellet containing the crude lysate synaptosomal proteins was resuspended in buffer $\mathrm{A}$, and protein lysate concentrations were determined by $\mathrm{A}_{280}$ spectrophotometry (NanoDrop). Lysates were stored at $-80^{\circ} \mathrm{C}$ until needed.

Coimmunoprecipitation. Samples from individual animals were processed in parallel throughout the coimmunoprecipitation (co-IP) assay. Four-hundred and fifty micrograms of each synaptosomal lysate was resuspended to a total volume of $1.4 \mathrm{ml}$ in cold lysis buffer (50 mM Tris, $150 \mathrm{~mm} \mathrm{NaCl}, 1 \% \mathrm{~N}$-dodecyl- $\beta$-D-maltoside, $0.1 \%$ cholesterol hemisuccinate $10 \%$ glycerol) with freshly added protease- and phosphatase-inhibitor cocktails (Sigma-Aldrich). Resuspended lysates were precleared with agarose-conjugated mouse IgG (Sigma-Aldrich) for $1 \mathrm{~h}$ at $4^{\circ} \mathrm{C}$, and the precleared lysates were then split into two tubes and immunoprecipitated for $1 \mathrm{~h}$ at $4^{\circ} \mathrm{C}$ with either no antibody $(20 \mu \mathrm{l}$ of agarose-conjugated IgG only) or with $10 \mu \mathrm{g}$ of mouse monoclonal antibody anti-SAP97 (NeuroMAb). The IP then continued overnight at $4^{\circ} \mathrm{C}$ with $25 \mu \mathrm{l}$ of EZview red agarose-conjugated Protein G (Sigma-Aldrich) added per tube. Agarose IPs were then stringently washed six times with lysis buffer (without any inhibitors), $15 \mathrm{~min}$ per wash at $4^{\circ} \mathrm{C}$, and proteins were eluted from the agarose IP with $50 \mu \mathrm{l}$ of $2 \times$ Laemmli sample buffer (Bio-Rad) supplemented with $5 \% \beta$-mercaptoethanol (Sigma-Aldrich). The samples were heated at $42^{\circ} \mathrm{C}$ for $10 \mathrm{~min}$ before immunoblotting.

Western blotting. Samples were separated by SDS-PAGE gels and transferred to Immobilon-P or PVDF membranes (Millipore, Invitrogen). Membranes were incubated in primary antibodies for GPER1 (C-term; (1:4000), SAP97 (1:6000), Phospho-Akt (Thr308), and total Akt (1:500, Cell Signaling Technology) and $\beta$-actin (1:1000, Sigma-Aldrich) overnight at $4^{\circ} \mathrm{C}$. Immunoblots were visualized by incubating with CleanBlot peroxidase reagent (Pierce) or anti-Rabbit/mouse-conjugated HRP (Thermo Scientific) and then Supesignal West Pico or Femto reagent (Pierce). Results are expressed as the ratio of phosphorylated protein to
Table 1. Distribution of GPER1-IR profiles in the hippocampus of male GPER1-KO mice

\begin{tabular}{llclllr}
\hline Subregion & Genotype & Dendrites & Spines & Terminals & Axons & \multicolumn{1}{l}{ Glia } \\
\hline CA1 S0 & WT & $35 \pm 6.6$ & $10.3 \pm 3.5$ & $6.3 \pm 2.0$ & $40.0 \pm 11.5$ & $18 \pm 1.5$ \\
& K0 & $2.0 \pm 1.0$ & $3.0 \pm 1.2$ & $2.0 \pm 1.0$ & $15.0 \pm 6.2$ & $9.6 \pm 2.1$ \\
DGCH & WT & $23.0 \pm 3.0$ & $7.3 \pm 1.2$ & $9.0 \pm 2.5$ & $84.6 \pm 6.9$ & $12.3 \pm 4.4$ \\
& K0 & $2.7 \pm 1.5$ & $0.33 \pm 0.33$ & $3.3 \pm 1.7$ & $52 \pm 14.4$ & $2.3 \pm 1.8$ \\
\hline
\end{tabular}

Average number of GPER1-labeled profiles \pm SEM from $360 \mu \mathrm{m}^{2}$ per lamina/animal ( $N=3$ each genotype).

total protein after correction for loading differences. Differences between treatment groups were analyzed by an unpaired Student's $t$ test.

\section{Results}

By light microscopy, GPER1-immunoreactivity is found in cell bodies and diffusely distributed throughout all hippocampal lamina

Consistent with findings in the rat hippocampus (Hammond et al., 2011), GPER1-IR is found in all lamina of the mouse hippocampus (Fig. 1A), Cells containing GPER1-IR were most prominent in the pyramidal cell layer (especially CA3), and interspersed in strata oriens and radiatum of CA1 and CA3, and in the hilus of the dentate gyrus (Fig. 1 B, C). Diffuse GPER1-IR was found in all lamina but was most dense in stratum lucidum of CA3 (Fig. 1D) and to a lesser extent in stratum lacunosummoleculare of CA1 (Fig. 1A). No nuclei with GPER1-IR were detected in any subregion. The pattern of GPER-1 was identical in males and females, regardless of cycle phase.

All GPER1 immunolabeling was abolished when the antibody was preadsorbed with the peptide against which the antiserum was raised (Fig. 1E). Moreover, GPER1-IR was greatly diminished in hippocampal tissue from mice carrying a GPER1-null mutation (Fig. $1 F$ ). In particular, GPER1-IR in granule cells was barely detectable and noticeably lighter in pyramidal cells and hilar interneurons. Moreover, most of the diffuse GPER1-IR was greatly diminished in all lamina. However, compared with other lamina, more diffuse GPER1-IR was detected stratum lacunosummoleculare of CA1, stratum lucidum of CA3 and the hilus of the dentate gyrus (Fig. $1 F$ ). Our EM analysis of GPER1-null mice (Table 1; see Discussion) revealed that the greater intensity of GPER1-IR in these latter regions is mostly due to the presence of labeled axons.

\section{By electron microscopy, GPER1-immunoreactivity is found presynaptically and postsynaptically in neurons and glia}

At the electron microscopic level, GPER1 labeling was found in all lamina of the dorsal hippocampus. Consistent with the light microscopic observations, no nuclei containing GPER1-IR were seen. Instead, GPER1-IR was exclusively extranuclear and was found in perikarya, dendrites, dendritic spines, axons, and terminals in neurons, as well as glia. The types of cells and profiles containing GPER-1-IR were similar in males and females. However, as described below, there were some sex and cycle differences in the number of labeled profiles.

Peroxidase reaction product for GPER1 was not detected in cell nuclei (Fig. 2A). This was confirmed in tissue labeled for GPER1 using silver-intensified immunogold (SIG; data not shown). Instead, peroxidase labeling for GPER1 was usually interspersed throughout the cytoplasm of soma (Fig. 2A,B) and dendritic shafts (Fig. 3). However, discrete patches of peroxidase immunoreactivity were detected on or near the plasma membrane of dendritic shafts (Fig. 3) and in dendritic spine heads or near the base of dendritic spines (Fig. $3 A, C$ ). In addition, GPER1-IR was seen near rough endoplasmic reticula (Fig. 2A, B) 
or near spine apparatus (Fig. 3C). Most of the dendritic shafts with GPER1-IR were in principal cells as reflected by the presence of associated spines and their location in CA1 stratum radiatum (Fig. 3B) and the dentate molecular layer (Fig. 3C). The localization of GPER1 was also confirmed using SIG, which although less sensitive than immunoperoxidase is more discrete (Milner et al., 2011). GPER1 SIG particles were found in CA1 stratum radiatum and the dentate molecular layer associated with dendritic membranes (see Fig. 6A) and in the cytoplasm of dendritic spines (see Fig. 6B). However, some GPER1-labeled dendritic shafts lacked spines, received numerous contacts, and were found in the dentate hilus, suggesting that they arose from interneurons (data not shown).

Within axons, GPER1-IR was localized near membranes suggesting involvement in cell signaling during axon transport (Cosker et al., 2008). In CA3 stratum lucidum, GPER1-IR was found in axons forming bundles (Fig. 4A) similar to what we have observed previously with mossy fiber axons containing enkephalin (Torres-Reveron et al., 2008). Axon terminals with GPER1-IR were small $(0.4-0.6 \mu \mathrm{m}$ in diameter) and contained numerous small clear vesicles (Fig. 4B). Terminals with GPER1-IR often formed asymmetric synapses on dendritic spines (data not shown) and axodendritic synapses (Fig. 4B). GPER1-IR was occasionally detected in large terminals with the morphology of mossy fibers (Pierce et al., 1999) in CA3 and the dentate gyrus (data not shown).

Glial cells labeled for GPER1 were found throughout the hippocampus (Fig. 5). Notably, GPER1-IR was found in glial processes adjacent to unlabeled axon terminals and dendritic spines (Fig. 5B). An astrocyte containing GPER1-IR formed a gap junction with an unlabeled astrocytic process in the dentate gyrus (Fig. 5A). GPER1-IR also was found in close proximity to blood vessels in an astrocytic endfeet apposed to the basement membrane (bm) of endothelial cells (Figs. 5C, 6C).

\section{Both presynaptic and postsynaptic} GPER1-IR is considerably reduced in mice carrying a GPER1-null mutation Two regions of the hippocampus from male mice carrying a GPER1-null mutation were chosen for quantitative EM analysis: strata oriens (SO) of CA1 and the central hilus of the dentate gyrus. In both regions, presynaptic (i.e., axons and axon terminals) and postsynaptic (i.e., dendritic shaft and spine) labeling was reduced (Table 1). Compared with wild-type mice, the numbers of GPER1-labeled dendrites
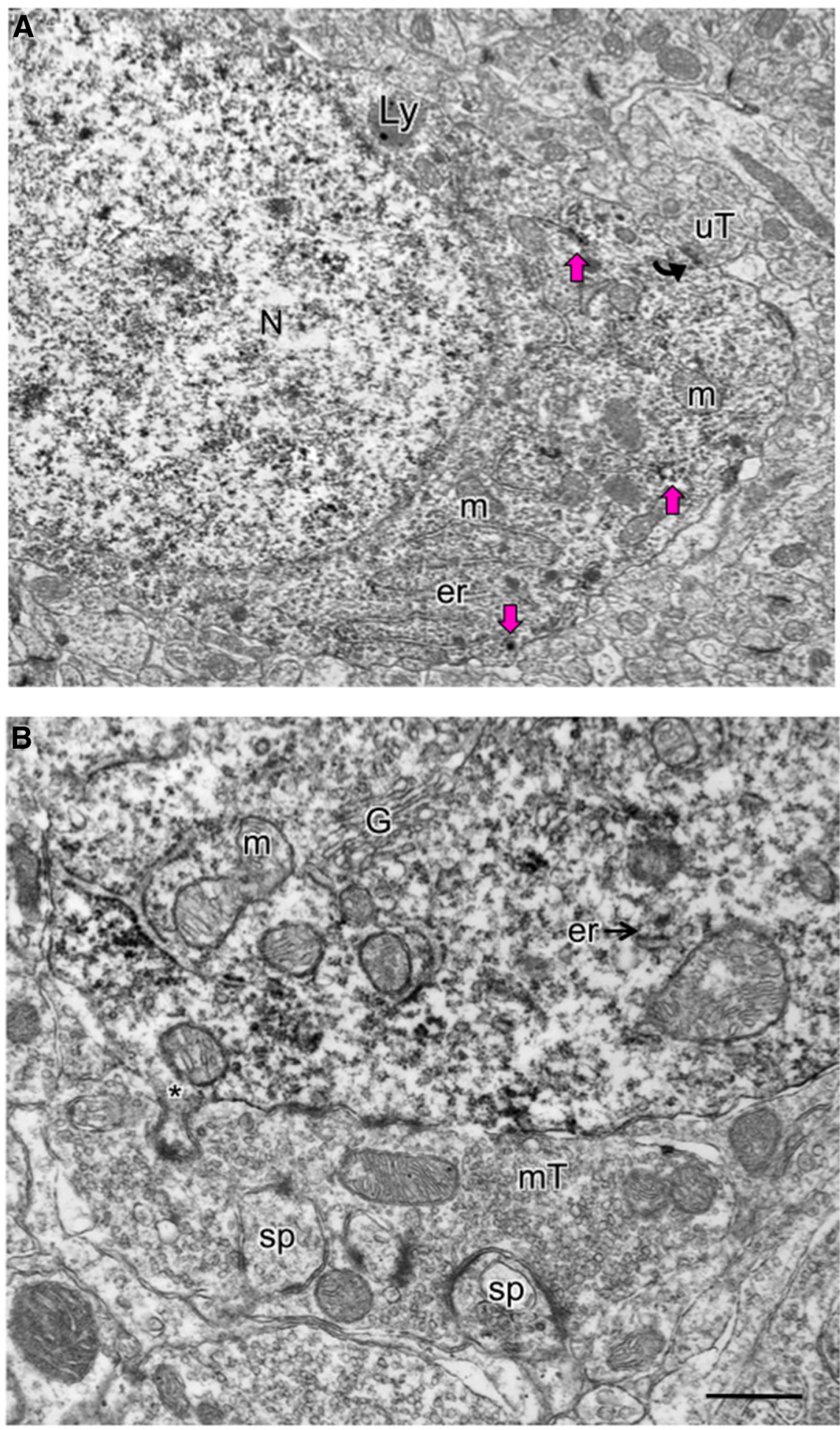

Figure 2. By electron microscopy, GPER1-IR is found in neuronal perikarya. $\boldsymbol{A}$, At low-magnification GPER1-labeling is seen throughout the cytoplasm in an interneuron from CA1 S0. The labeled perikaryon is contacted (curved arrow) by an unlabeled terminal (uT). $\boldsymbol{B}$, A high-magnification photomicrograph from the hilus of the dentate gyrus shows an unlabeled mossy fiber terminal (mT) contacting a GPER1-labeled soma and somatic spine (star). The mossy fiber terminal also contacts two unlabeled dendritic spines (sp). In both $\boldsymbol{A}$ and $\boldsymbol{B}$, clusters of GPER1-IR occasionally are found near endoplasmic reticula (magenta arrows; er). G, Golgi apparatus; m, mitochondria; N, nucleus (images from a proestrous mouse). Scale bar, $500 \mathrm{~nm}$.

$\left(t_{(4)}=4.97 ; p=0.0076\right)$ and glial $\left(t_{(4)}=3.13 ; p=0.0354\right)$ profiles in GPER1-null mice were significantly reduced in CA1. In the dentate gyrus, number of GPER1-labeled dendrites $\left(t_{(4)}=6.1\right.$; $p=0.0037)$ and dendritic spines $\left(t_{(4)}=5.6 ; p=0.0050\right)$ profiles was significantly reduced in the GPER1-null mice compared with the 

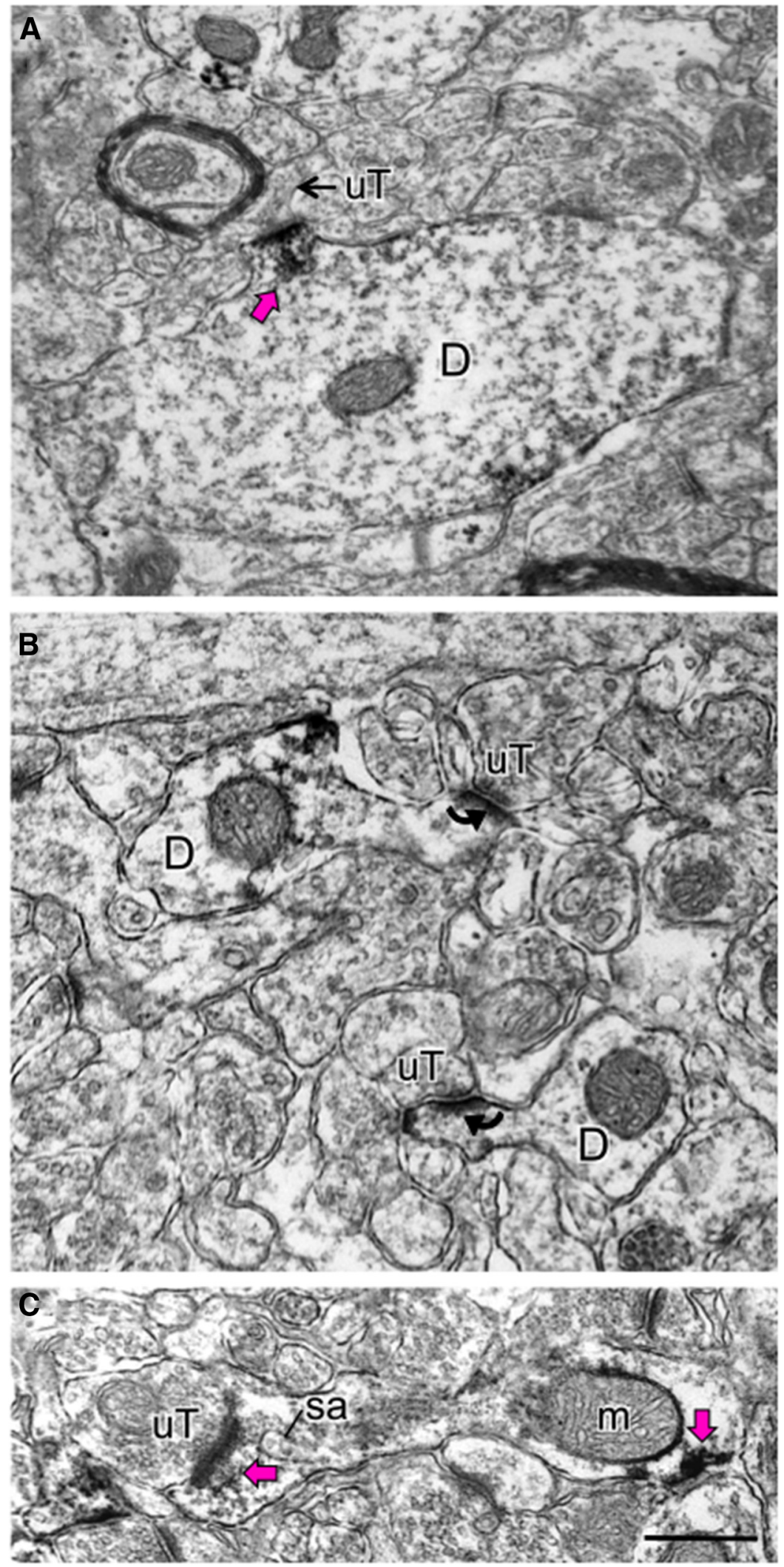

Figure 3. GPER1-IR is found in dendrites and dendritic spines associated with the plasma membrane and synapses. $A$, In this dendritic shaft (D), GPER1-IR is in discrete patches (magenta arrows) near a synaptic contact from an unlabeled terminal (uT; CA1 SLM). B, GPER1-IR is found in dendrites that emanate spines contacted (curved arrows) by uTs. In the upper dendrite, a patch of GPER1-IR is near the plasma membrane of the dendritic shaft. In the bottom dendrite, GPER1-IR is affiliated with the synapse (CA1 near SR). $C$, In this dendritic spine contacted by an uT, clusters of GPER1-IR are found near the synapse (magenta arrow, left) and near the plasma membrane (magenta arrow, right) and a mitochondrion (m). sa, Spine apparatus (DG OML). Scale bars, $500 \mathrm{~nm}$. wild-type mice. In both regions, the numbers of GPER1 other types of labeled profiles in GPER1-null mice were reduced but these values were not significant largely due to the variability between mice.

Sex and estrous cycle phase affected the number of detectable GPER1-labeled profiles in select subregions

Our previous studies in mice showed that sex and estrous cycle phase can affect the number of detectable profiles containing $\mathrm{ER} \alpha$ and $\mathrm{ER} \beta$ in select subregions (Mitterling et al., 2010). Thus, we sought to determine whether these parameters similarly altered the number of detectable profiles containing GPER1.

GPER1-labeled profiles were counted from 12 different hippocampal laminae lacking principal cell perikarya in CA1, CA3, and dentate gyrus, for $4320 \mu \mathrm{m}^{2}$ total per mouse. Table 2 shows the average number of each type of GPER1-labeled profile (i.e., dendrites, spines, terminals, axons, and glia) from each lamina of the 12 animals. Less than $1 \%$ of labeled profiles were unidentifiable or perikarya, and these were excluded from the analysis. When calculated either as a whole (i.e., all 12 lamina in the three regions combined) or each region and lamina separately, dendrites $(\sim 30 \%)$ and axons ( $\sim 45 \%)$ were the most numerous profiles (Tables 2, 3 ).

When data were pooled for all lamina and all subregions (i.e., CA1, CA3, and dentate gyrus), females and males had similar proportions of GPER1-labeled profiles. No significant differences in the overall number of GPER1-labeled profiles were seen between males and females, regardless of cycle stage. However, one-way ANOVA showed significant interactions between estrous cycle stage and sex in the overall number of dendrites $\left(F_{(3,140)}=3.276, p=0.0230\right)$, axons $\left(F_{(3,140)}=2.816, p=0.0414\right)$, and glial $\left(F_{(3,140)}=7.44, p=0.0001\right)$ profiles. Post hoc analysis revealed significantly fewer GPER1-immunoreactive axons profiles were seen in estrous females compared with proestrous females $(p=0.0263)$. Similarly, significantly fewer GPER1-immunoreactive glial profiles were seen in estrous females compared with proestrous females $(p=$ $0.0001)$, diestrous females $(p=0.0026)$, and males $(p=0.0257)$. Conversely, post hoc analysis showed significantly more GPER1-labeled dendrites in estrous females compared with proestrous $(p=0.0415)$ and diestrous ( $p=0.0333)$ females.

When the number of GPER1-labeled profiles was subdivided into different regions, one-way ANOVA revealed 
significant sex and cycle interactions in the CA1 and dentate gyrus only.

In the CA1, one-way ANOVA showed significant sex and cycle interactions in the number of axon profiles $\left(F_{(3,44)}=\right.$ 4.95, $p=0.0048)$. Post hoc analysis showed significantly fewer GPER1labeled axons in estrous females compared with diestrous females $(p=0.0047)$ and males $(p=0.0250)$, and a trend for fewer axons than proestrous females ( $p=$ 0.0588 ). In the dentate gyrus, one-way ANOVA showed significant interaction between sex and estrous cycle in axon terminals $\left(F_{(3,56)}=4.67, p=0.0056\right)$ and $\operatorname{glial}\left(F_{(3,56)}=11.02, p<0.0001\right)$ profiles. Post hoc analysis showed significantly fewer GPER1-labeled axon terminals in diestrous $(p=0.0037)$ and a trend toward fewer GPER1-labeled terminals in proestrous females $(p=0.063)$ and males $(p=$ 0.072) compared with estrous females. Conversely, post hoc analysis showed fewer glial profiles in estrous females compared with proestrous females $(p<$ $0.0001)$, diestrous females $(p=0.0017)$, and males $(p<0.0418)$. Moreover, males had significantly fewer glial profiles than proestrous females ( $p=0.0285)$.

\section{The GPER1 agonist, G1, increases the levels of PSD-95-IR in CA3}

Previously we found that the levels of PSD-95, a correlate of excitatory synapse levels, fluctuate over the estrous cycle in mice (Spencer et al., 2010) and after estrogen replacement in mice and rats (Waters et al., 2009; Spencer-Segal et al., 2012). This experiment determined whether G1 similarly affects PSD-95 levels. For this, ovariectomized female mice were administered vehicle, EB, or the GPER1 agonist, G1. Six hours postadministration, PSD95-IR was measured by light microscopic peroxidase densitometry in all lamina of $\mathrm{CA} 1, \mathrm{CA} 3$, and the dentate gyrus (Fig. 7A). No significant effects of either EB or G1 on the levels of PSD95-IR in any lamina of CA1 or the dentate gyrus were observed (data not shown). The lack of change of EB on PSD95- levels is consistent with previous results (Spencer-Segal et al., 2012). However, one-way ANOVA revealed a significant effect of treatment on the levels of PSD95 in CA3 stratum radiatum $\left(F_{(2,9)}=6.35 ; p=0.0190\right)$, stratum lucidum $\left(F_{(2,9)}=4.53 ; p=0.0435\right)$, and stratum oriens $\left(F_{(2,9)}=8.85, p=\right.$ 0.0075). Post hoc analysis demonstrated that $6 \mathrm{~h}$ after $\mathrm{G} 1$ administration, the levels of PSD-95 significantly increased in stratum radiatum $(p=0.016)$, stratum lucidum $(p=0.039)$, and stratum oriens
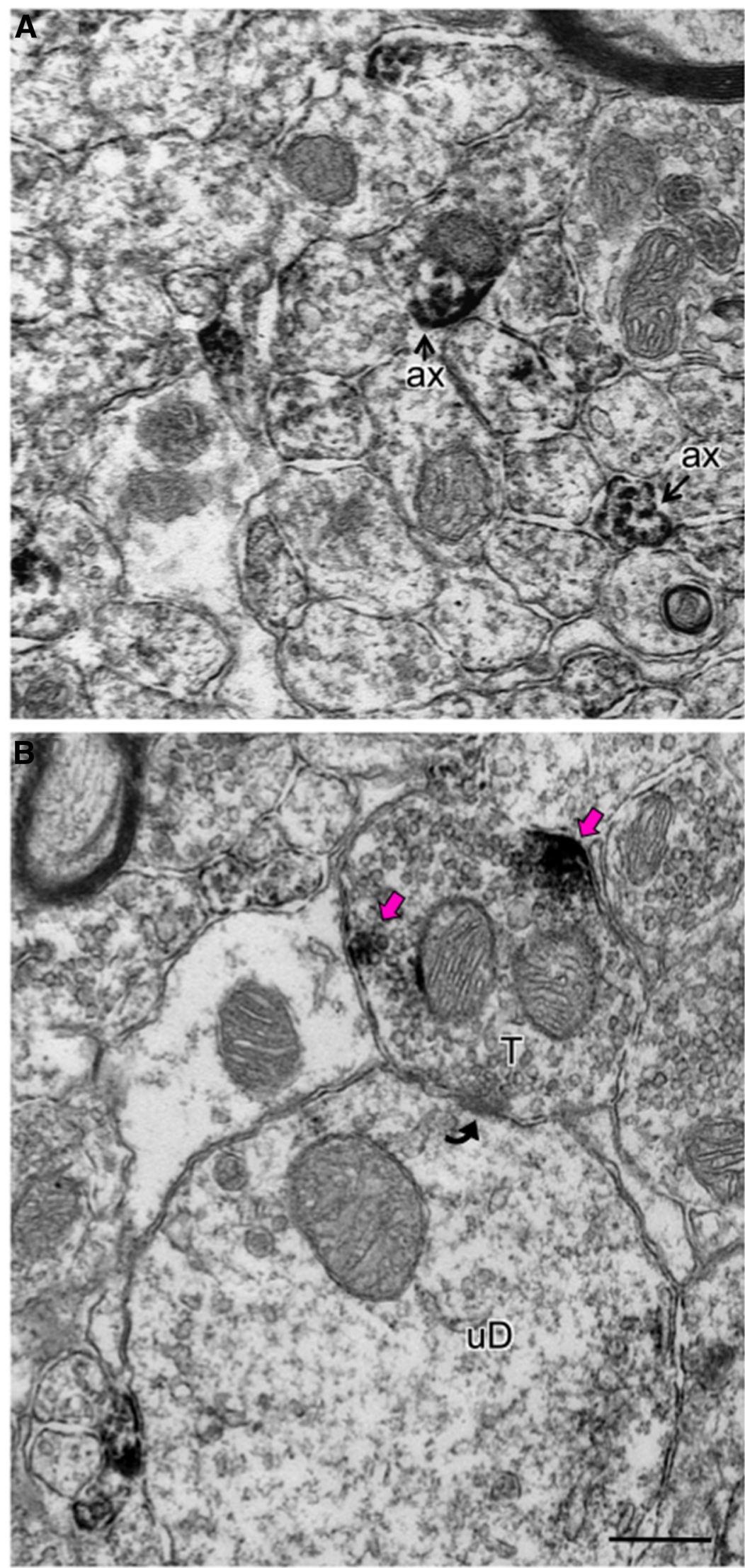

Figure 4. GPER1-IR is found in axons and axon terminals. $A, \operatorname{In}$ CA3 stratum lucidum, GPER1-IR is found in numerous unmyelinated axons (ax) that are often in bundles with unlabeled axons. $\boldsymbol{B}$, Clusters (magenta arrows) of GPER1-IR are found in small synaptic vesicles near the plasma membrane of a terminal. The terminal contacts (curved arrow) an unlabeled dendrite (UD) that is also adjacent to a GPER1-labeled axon (DG hilus). Scale bar, $500 \mathrm{~nm}$. 

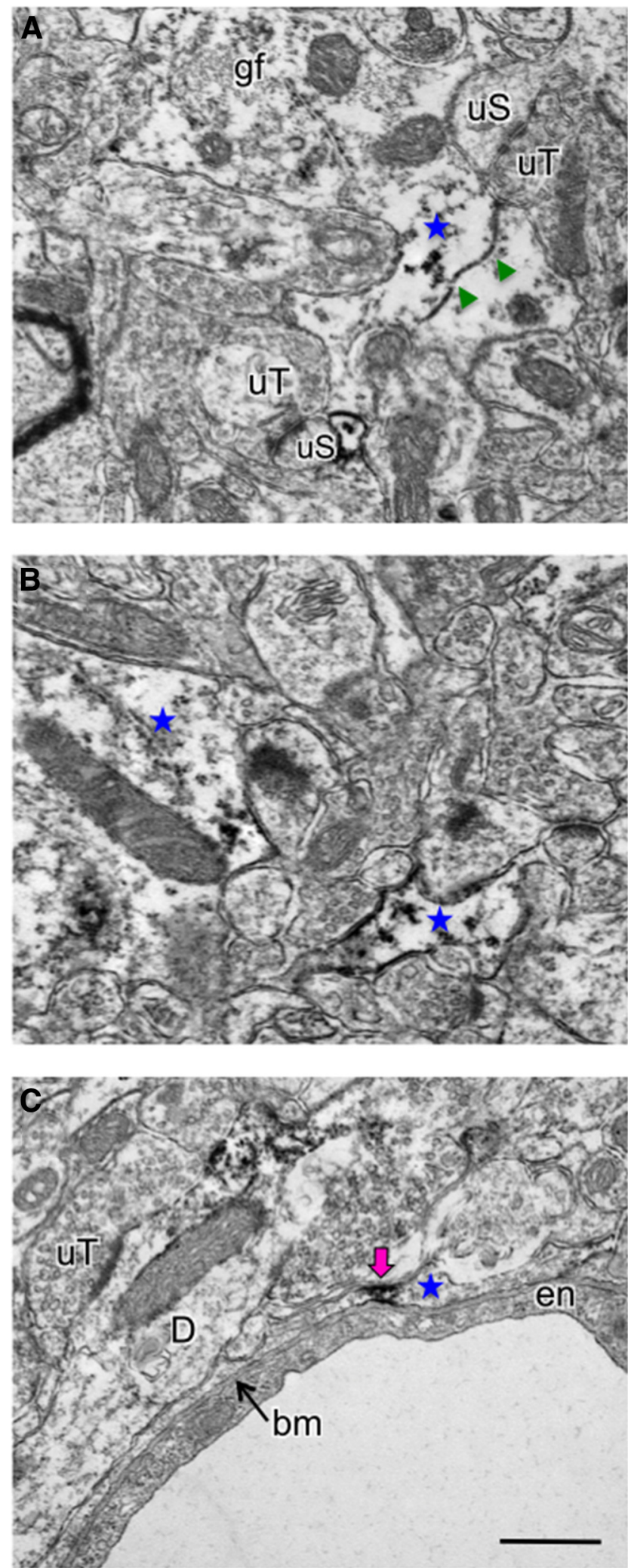

Figure 5. GPER1-IR is found in glial processes, some of which are astrocytes. $A$, GPER1-IR is found in an astrocytic process (blue star), identified by glial filaments ( $g$ ), that forms a gap junction (green arrowheads) with an unlabeled astrocytic process (proestrous, DG OML). $\boldsymbol{B}$, Clusters of GPER1-IR are found in two glial profiles (blue star). In both $\boldsymbol{A}$ and $\boldsymbol{B}$, the GPER1-labeled glial processes are adjacent to terminal (uT)-spine (US) complexes (proestrous CA1 SLM).C, GPER1-IR (magenta arrow) isfound in an astrocytic endfoot (blue star) apposed to the basement membrane (bm) of a blood vessel endothelial cell (en). A GPER1-labeled dendrite (D) contacted by an unlabeled terminal (UT) is apposed (arrowheads) to the astrocytic endfoot (proestrous (A3 SR). Scale bar, $500 \mathrm{~nm}$.
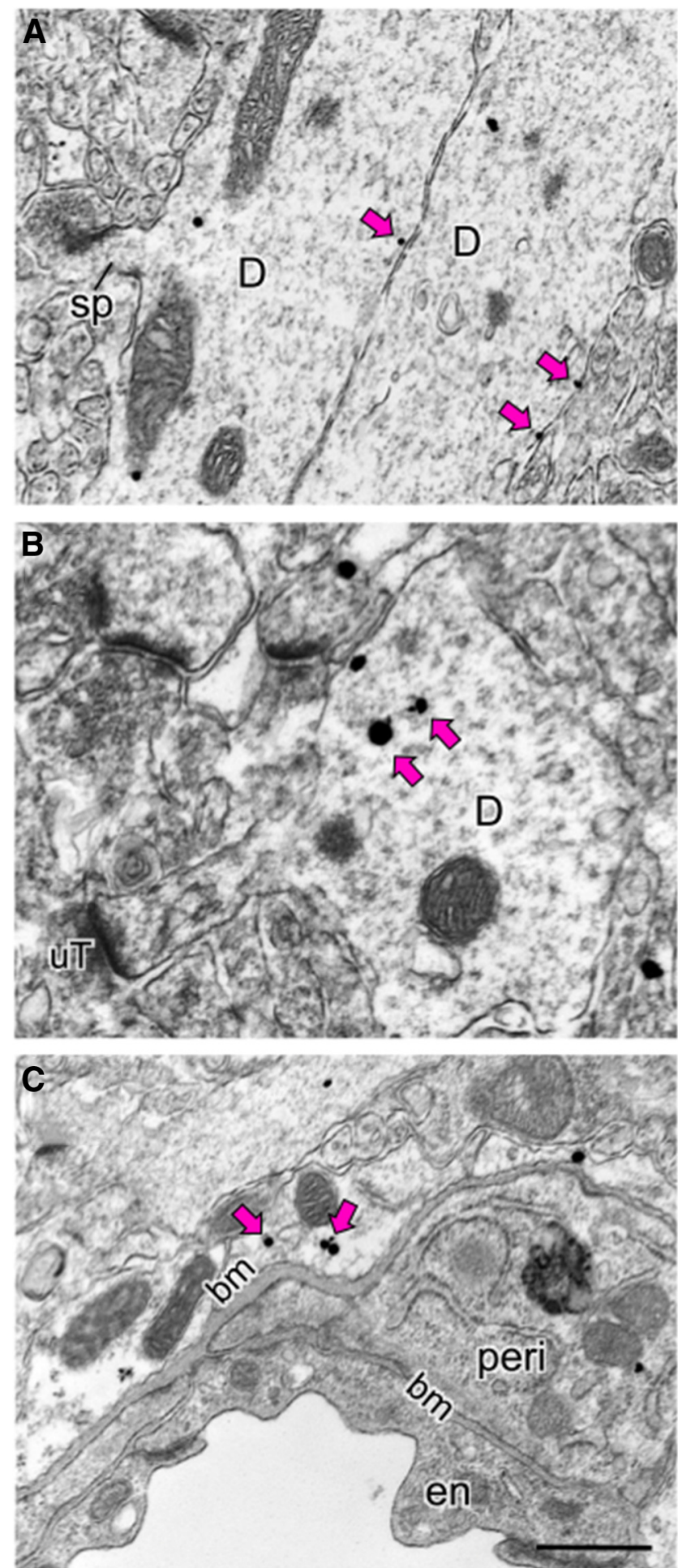

Figure 6. GPER1 is found in cytoplasmic and membrane locations labeled with SIG particles. $A$, GPER1 labeled with SIG (magenta arrows) is found in adjacent dendrites (D) in the cytoplasm (left) near a spine (sp) and on the membrane (left and right). B, GPER1 SIG particles (magenta arrows) are found in a dendrite near a spine synapsing on an unlabeled terminal (UT). C, GPER1 SIG particles (magenta arrows) are found in an astrocytic endfoot apposed to the bm of a blood vessel endothelial cell (en) and pericyte (peri). Scale bar, $500 \mathrm{~nm}$.

$(p=0.0064$; Fig. $7 C-E)$. Moreover, $6 \mathrm{~h}$ after $\mathrm{EB}$ there was a trend for the levels of PSD95-IR to increase in stratum oriens of CA3 $(p=0.058$; Fig. $7 C)$. Representative micrographs of PSD-95 labeling of the CA3 from oil, EB and G1 administered mice are shown in Figure $7 B$. 
Table 2. GPER1-labeled profiles in individual hippocampal lamina

\begin{tabular}{|c|c|c|c|c|c|c|}
\hline Subregion & Lamina & Dendrites & Spines & Terminals & Axons & Glia \\
\hline \multirow[t]{4}{*}{ CA1 } & so & $33.92 \pm 3.68$ & $19.08 \pm 3.44$ & $7.58 \pm 2.29$ & $29.5 \pm 5.81$ & $19.58 \pm 3.45$ \\
\hline & NSR & $33.58 \pm 2.92$ & $16.33 \pm 2.22$ & $6.08 \pm 1.40$ & $25.5 \pm 4.61$ & $18.33 \pm 3.17$ \\
\hline & DSR & $33.17 \pm 3.49$ & $13.58 \pm 1.96$ & $6.17 \pm 1.55$ & $26.5 \pm 5.75$ & $14.67 \pm 2.10$ \\
\hline & SLM & $45.17 \pm 4.76$ & $9.25 \pm 1.27$ & $3.5 \pm 0.94$ & $20.08 \pm 4.93$ & $12 \pm 2.33$ \\
\hline \multirow[t]{3}{*}{ CA3 } & so & $44.42 \pm 6.44$ & $13.92 \pm 2.05$ & $5.08 \pm 0.82$ & $29.17 \pm 3.20$ & $15.33 \pm 1.82$ \\
\hline & SLU & $22.42 \pm 1.87$ & $5.58 \pm 1.23$ & $5.25 \pm 1.44$ & $87.25 \pm 15.07$ & $4.08 \pm 1.06$ \\
\hline & SR & $33.92 \pm 4.54$ & $8 \pm 0.95$ & $3.83 \pm 1.01$ & $25.08 \pm 4.08$ & $9.67 \pm 1.90$ \\
\hline \multirow[t]{5}{*}{ DG } & OML & $31.33 \pm 4.36$ & $9.67 \pm 2.26$ & $4.92 \pm 0.88$ & $18.08 \pm 4.12$ & $13.67 \pm 2.86$ \\
\hline & MML & $39.42 \pm 5.47$ & $10.33 \pm 1.55$ & $5.58 \pm 1.31$ & $18.25 \pm 2.97$ & $14 \pm 3.06$ \\
\hline & IML & $29.92 \pm 3.99$ & $9.75 \pm 1.82$ & $7.25 \pm 2.61$ & $19.17 \pm 4.61$ & $13.42 \pm 2.60$ \\
\hline & SGH & $18.75 \pm 3.17$ & $7.17 \pm 2.16$ & $9.25 \pm 2.27$ & $51.42 \pm 6.27$ & $10.58 \pm 2.35$ \\
\hline & $\mathrm{CH}$ & $16.58 \pm 1.84$ & $6.42 \pm 0.99$ & $9.67 \pm 1.88$ & $73.83 \pm 10.78$ & $9.92 \pm 2.07$ \\
\hline
\end{tabular}

Average number of profiles from three stages of females and males ( $N=12 ; 360 \mu \mathrm{m}^{2}$ per lamina/animal). SO, stratum oriens; NSR, near stratum radiatum; DSR, distal stratum radiatum; SLM, stratum lacunosum-moleculare; SL, stratum lucidum; DG, dentate gyrus; OML, outer molecular layer; MML, middle molecular layer; IML, inner molecular layer; $\mathrm{SGH}$, subgranular hilus; $\mathrm{CH}$, central hilus.

Table 3. Distribution of GPER1-IR profiles in the hippocampus of female cycling and male mice

\begin{tabular}{|c|c|c|c|c|c|c|}
\hline Subregion & Cycle/sex & Dendrites & Spines & Terminals & Axons & Glia \\
\hline \multirow[t]{4}{*}{ CA1 } & Proestrous & $125.7 \pm 6.0$ & $69.3 \pm 7.7$ & $18.7 \pm 2.0$ & $110.0 \pm 10.3$ & $78.0 \pm 6.6$ \\
\hline & Estrous & $180.0 \pm 11.1^{c}$ & $52.0 \pm 3.7^{a}$ & $12.0 \pm 2.1$ & $41.3 \pm 5.1^{c}$ & $40.3 \pm 5.1^{c}$ \\
\hline & Diestrous & $134.3 \pm 4.7$ & $60.0 \pm 3.5$ & $30.3 \pm 4.5^{d}$ & $135.7 \pm 10.3$ & $65.3 \pm 4.6$ \\
\hline & Male & $143.3 \pm 6.7$ & $51.7 \pm 4.3$ & $32.3 \pm 3.1$ & $119.3 \pm 10.5$ & $74.7 \pm 5.4$ \\
\hline \multirow[t]{4}{*}{ CA3 } & Proestrous & $100.7 \pm 7.4$ & $29.0 \pm 3.4$ & $13.7 \pm 1.7$ & $163.0 \pm 34.6$ & $24.0 \pm 2.6$ \\
\hline & Estrous & $111.7 \pm 13.7$ & $37.0 \pm 3.6^{b}$ & $22.0 \pm 2.7^{c}$ & $117.3 \pm 21.2^{b}$ & $27.3 \pm 5.0$ \\
\hline & Diestrous & $102.3 \pm 7.4$ & $25.0 \pm 3.6$ & $10.7 \pm 2.1$ & $171.7 \pm 21.5$ & $38.7 \pm 4.2^{d}$ \\
\hline & Male & $88.3 \pm 13.1$ & $19.0 \pm 3.3$ & $10.3 \pm 1.8$ & $114.0 \pm 19.7$ & $26.3 \pm 4.6$ \\
\hline \multirow[t]{4}{*}{ DG } & Proestrous & $117.0 \pm 6.7$ & $50.3 \pm 4.8$ & $32.3 \pm 2.5$ & $244.3 \pm 25.5$ & $95.3 \pm 5.4$ \\
\hline & Estrous & $171.0 \pm 10.9^{c}$ & $43.3 \pm 2.9$ & $60.7 \pm 6.0^{c}$ & $117.0 \pm 11.5^{c}$ & $21.3 \pm 1.9^{c}$ \\
\hline & Diestrous & $103.0 \pm 6.8$ & $34.7 \pm 3.3^{a}$ & $20.7 \pm 1.4$ & $165.7 \pm 13.4$ & $72.3 \pm 4.8$ \\
\hline & Male & $153.0 \pm 9.8$ & $45.0 \pm 3.3$ & $33.0 \pm 2.3$ & $196.0 \pm 17.1$ & $57.3 \pm 3.6$ \\
\hline Total & & $1530.3 \pm 104.3$ & $516.3 \pm 47.3$ & $296.7 \pm 32.2$ & $1695.3 \pm 200.6$ & $621.0 \pm 54.0$ \\
\hline
\end{tabular}

Average number of GPER1-labeled profiles \pm SEM from $4320 \mu \mathrm{m}^{2}$ per animal ( $N=3$ each proestrous, estrous, diestrous, and male) One-way ANOVA compared females ( $p<0.05$ compared with the following: ${ }^{a}$ proestrous, ${ }^{b}$ diestrous, 'proestrous and diestrous, ${ }^{d}$ proestrous and estrous). Males are shown for reference.

\section{GPER1 coimmunoprecipitates with the} postsynaptic scaffolding protein SAP97 SAP97 (Dlg1) is a member of the membrane-associated guanylate kinase (MAGUK) family of scaffolding proteins that can be found in the dendritic spine at or near the postsynaptic density (Verpelli et al., 2012). SAP97 and the MAGUK protein PSD-95 both contain internal PSD95/ $\mathrm{Dlg} 1 / \mathrm{ZO} 1$ (PDZ) ligand binding domains and can associate with G-protein coupled receptors (GPCRs) to form a protein scaffolding complex (Romero et al., 2011).

The apparent molecular weight of GPER1 monomeric recombinant protein expressed in 293 cells is $\sim 44 \mathrm{kDa}$ (Filardo et al., 2000); however, in the SAP97 co-IP and in the crude synaptosomal lysate preparations (Fig. 8), endogenous mouse GPER1 was detected as at $\sim 90,95$, and $105 \mathrm{kDa}$. Because it has been reported that other hormone sensitive GPCRs can exist as dimeric forms (Rivero-Müller et al., 2010), these bands may correspond to homodimers, as well as heterodimers with other GPCRs (Akama et al., 2013). The multiple bands may also reflect posttranslational modifications such as glycosylation or phosphorylation that are important for the
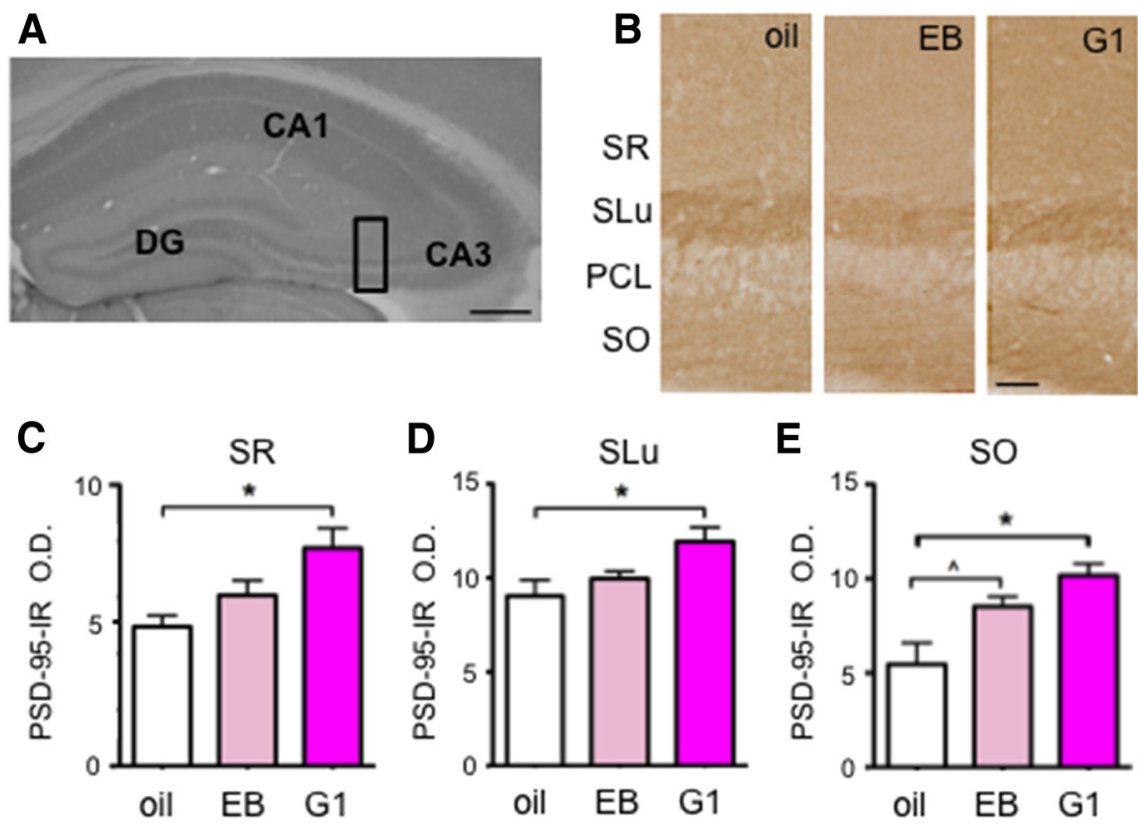

Figure 7. The GPER1 agonist, G1, increases the levels of PSD-95-IR in the CA3 region of the mouse hippocampus. $A$, Lowmagnification light micrograph shows PSD-95-IR CA1, CA3, and the dentate gyrus in coronal section of the dorsal hippocampus. Boxed region shows region that is enlarged in $\boldsymbol{B}$. Scale bar, $500 \mu \mathrm{m}$. $\boldsymbol{B}$, Representative light micrographs of the CA3 from oil, EB and G1 administered mice. Diffuse PSD-95-IR is found throughout all lamina (except principal cell layers). Scale bar, $100 \mu \mathrm{m} . C, D, E$, In stratum oriens (SO), lucidum (SLu), and radiatum (SR) of CA3, the optical density (0.D.) of PSD95-IR is significantly increased $6 \mathrm{~h}$ following $\mathrm{G} 1$ administration ( $\left.{ }^{*} p<0.01\right)$. In S0 of CA3 only, PSD95-IR tended to increase $(\hat{p}=0.058) 6 \mathrm{~h}$ following EB administration; $N=4$ mice/group. 
A

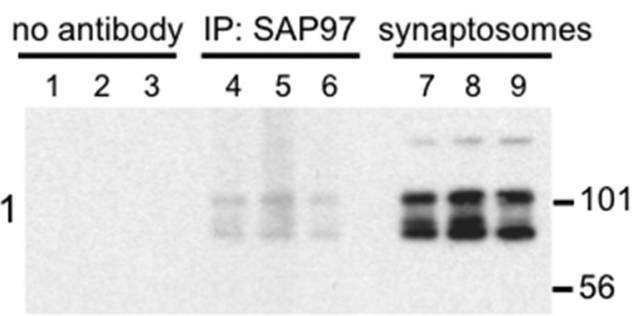

B

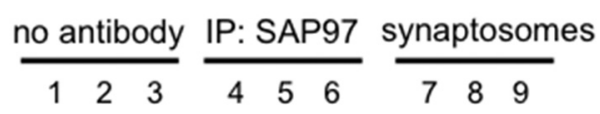

IB: SAP97

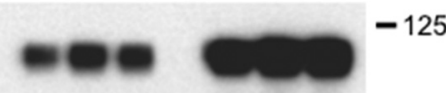

$-101$

Figure 8. GPER1 coimmunoprecipitates with the spine scaffolding protein SAP97 in the mouse hippocampus. A, SAP97-IP, GPER1 protein was detected by immunoblotting (IB; lanes 4-6), and GPER1 protein was not detected in the IP-negative control (lanes 1-3). Crude synaptosomal lysates were prepared from three adult female mouse hippocampi (hc $1-\mathrm{hc} 3$ ), and the individual lysates were incubated without (lanes 1-3) or with (lanes 4-6) anti-SAP97 antibody. $\boldsymbol{B}$, In parallel, $0.1 \%$ of each synaptosomal lysate starting material was also positive for GPER1 protein (lanes 7-9). Bottom, IP (lanes 4-6) and lysates (lanes 7-9) are IB-positive for SAP97 protein.

diverse physiological functionality of GPCRs (Bulenger et al., 2005; Rivero-Müller et al., 2010; Zheng et al., 2013). To support this interpretation, we did a prolonged exposure of the immunoblot to film and eventually revealed an additional faint $40-50 \mathrm{kDa}$ secondary protein band (data not shown) that likely represents unmodified immature GPER1.

\section{G1, the GPER1 agonist, does not replicate EB-induced phosphorylation of Akt}

Phosphorylation of Akt is implicated in estradiol's effects on synaptic plasticity and increased PSD-95 expression (Akama and McEwen, 2003). Ovariectomized female mice were administered vehicle, $\mathrm{EB}$, or G1. The ratio of $\mathrm{pAKT} / \mathrm{AKT}$ was increased in the dorsal hippocampus $6 \mathrm{~h}$ after EB treatment compared with vehicle treatment $(t$ test, $p<0.05$; Fig. $9 A, B)$. In contrast, $\mathrm{G} 1$ treatment did not alter the ratio of pAKT/AKT ( $t$ test, $p>0.05$; Fig. $9 A, B$ ). Because G-protein-coupled receptor activation is rapid, to determine whether $\mathrm{G} 1$ would increase $\mathrm{pAKT}$ at a shorter time point, pAKT was examined $30 \mathrm{~min}$ after treatment; however, neither $30 \mathrm{~min}$ of G1 or EB increased the pAKT/AKT ratio ( $t$ test, $p>0.05$; data not shown).

\section{Discussion}

Our electron microscopic studies revealed abundant extranuclear labeling for GPER1 throughout the mouse hippocampus. In particular, extranuclear GPER1 in neurons and glia is well positioned to influence hippocampal functions through local actions via extranuclear steroid signaling. Sex and estrous cycle phase influence the number of GPER1-labeled profiles that may have important implications for the sensitivity of hippocampal function to circulating ovarian steroids and endogenous neurosteroids. Activation of GPER1 replicated the estradiol-induced increase in PSD-95, although it did not increase Akt phosphorylation. GPER1 synaptic actions may also be regulated through its interaction with SAP97 and PSD-95. This study is an important step toward understanding the mechanisms by which circulating ovarian steroids influence hippocampal plasticity.

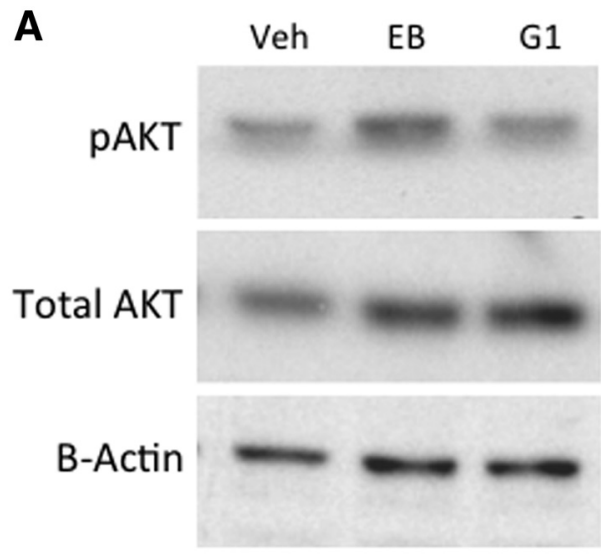

B

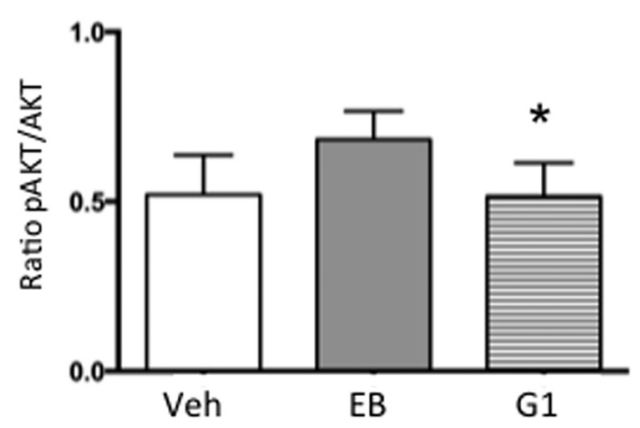

Figure 9. The GPER1 agonist, G1, does not increase levels of phosphorylated AKT in the mouse hippocampus. $A$, Examples of Western blots showing the effects of vehicle (veh), EB, or G1 $6 \mathrm{~h}$ after administration of pAKT or total AKT. B-actin is the loading control. $\boldsymbol{B}$, Six hours after administration of EB $\left({ }^{*} p<0.05\right)$ pAKT/ total AKT was increased compared with Vehicle (Veh), whereas $\mathrm{G} 1$ was not.

\section{Methodological considerations}

The antibody for GPER1 used in here has been well characterized in previous studies (Filardo et al., 2000; Akama et al., 2013). The antibodies used in this study allowed localization of GPER1, but may not distinguish between homomers, homodimers, or heterodimers or different receptor isoforms or splice variants because low levels of GPER1-labeling persisted in the GPER1-null mice. In particular, axonal labeling in the dentate gyrus was only reduced $\sim 30 \%$ and glial labeling in CA1 was only reduced $\sim 50 \%$. Thus, the antibody, in part, recognizes some other form of GPER1 in these cases.

\section{Estrous cycle affects the expression of extranuclear hormone receptors}

The present study adds to the growing body of evidence that gonadal steroid levels can affect the expression of ERs in the rodent hippocampus (Romeo et al., 2005; Mitterling et al., 2010). In particular, our previous studies in mice have shown that when circulating estradiol levels are high, the numbers of profiles containing extranuclear ER $\alpha$ - and ER $\beta$-labeling are low and vice versa (Mitterling et al., 2010). Moreover, females, regardless of estrogen state, have higher numbers of $\mathrm{ER} \alpha$-labeled profiles than males (Mitterling et al., 2010). This suggests that circulating estradiol downregulates the expression of extranuclear ERs similar to nuclear receptors (Weiland et al., 1997). In contrast, the numbers of GPER1-labeled axons and terminals, and to a lesser extent dendrites, were most different in estrous compared with other phases and males. However, the direction of change varied depending on hippocampal subregion. Consistent with the classical 
ERs, GPER1-IR was present in fewer profiles in males than proestrous females.

\section{GPER1 is positioned for local modulation of hippocampal function}

In the murine hippocampus, estradiol alters the dendritic spine morphology but not the overall number of spines (Li et al., 2004; $\mathrm{Xu}$ and Zhang, 2006). The widespread presence of profiles containing ER $\alpha$-, ER $\beta$-, and now GPER1-IR throughout the hippocampus suggests that these changes may occur via the direct action of ovarian steroids.

In the rat hippocampus, estrogens increase dendritic spine density (Woolley and McEwen, 1993), particularly the proportion of "mushroom" shaped spines which are believed to be more mature (González-Burgos et al., 2005), and increase multisynaptic boutons (Woolley et al., 1996). The outcome of estrogeninduced synapse formation in rats and mice is likely to increase synaptic strength; however, species differences in the mechanisms regulating spine dynamics exist. For example, estradiol regulation of synaptic proteins, including PSD-95, in rats is limited to the CA1 region (Brake et al., 2001; Lee et al., 2004; Waters et al., 2009), whereas in mice changes occur throughout the hippocampus (Li et al., 2004; Spencer et al., 2008a). Both estradiol and the GPER1 agonist G1 increased PSD-95 expression. GPER1 effects on PSD-95 do not coincide with increased AKT phosphorylation, suggesting that GPER1 actions occur via another route. This divergence in G1 and estradiol actions has also been identified during estradiol-mediated neuroprotection after ischemia (Kosaka et al., 2012).

Dendritic spines are known to mediate excitatory neurotransmission (Peters et al., 1991) and are believed to be important in the induction of long-term potentiation (LTP; Yuste and Bonhoeffer, 2004). Ovarian hormones, particularly estrogens, can enhance the magnitude of LTP, and regulate glutamatergic NMDA receptor mediated neurotransmission, as well as expression and distribution within dendritic spines (Woolley et al., 1997; Gazzaley et al., 2002; Smith and McMahon, 2006). A first glimpse into GPER1's role in neurotransmission in the brain suggests that it regulates the balance of excitatory and inhibitory signaling in the amygdala (Tian et al., 2013). Also, the GPER1 agonist G1 is as effective as estradiol in improving hippocampaldependent memory performance in female rats (Hammond and Gibbs, 2011), whereas antagonists impair learning (Hammond et al., 2012).

The abundance of GPER1-IR in glial cells suggests that they may have distinct roles in the hippocampal response to ovarian steroids. Little attention has been paid to the role of glial cells in this process. The glial cell type labeled with GPER1 is unknown, however, their location near synapses and blood vessels suggest GPER1 is present in microglia and astrocytes. In female rats, conflicting reports have shown increases or decreases in astrocytic volume during proestrous (Klintsova et al., 1995; Arias et al., 2009). Whether this is linked to changes in any type of ERs is unclear. Glial cells have been shown to mediate the neuroprotective effects of estradiol (Sortino et al., 2004). Although GPER1 activation has been implicated in estradiol-mediated neuroprotection (Lamprecht and Morrison, 2014; Tang et al., 2014), whether this is due to glial localization in unknown. However, GPER1's presence in glial cells suggests another route for estradiol's widespread effects on hippocampal function.

\section{GPER1 regulates PSD-95}

PSD-95 protein expression is regulated by the post-transcriptional processing of localized PSD-95 mRNA transcripts (Bence et al., 2005; LiuYesucevitz et al., 2011). Localized transcripts and the proteins that constitute the requisite translational machinery are found in the postsynaptic spine compartment (Asaki et al., 2003). A key regulator of protein translation is the Akt/mTOR signal transduction pathway (Kindler and Kreienkamp, 2012). Ligand-dependent GPCR activation can directly or indirectly initiate the translation of mRNA transcripts (Dorsam and Gutkind, 2007; Rozengurt, 2007; Musnier et al., 2010) and GPER1 activation initiates the Akt signaling pathway (Prossnitz et al., 2008), suggesting that estrogens can enhance PSD-95 immunoreactivity in the mouse hippocampus via GPER1 and the Akt/mTOR signaling pathway. We have previously demonstrated that estradiol-stimulated Akt activation, as determined by phosphorylated Akt immunoreactivity, occurs in CA1 dendritic spines (Znamensky et al., 2003), and we have also demonstrated that estradiol stimulates PSD-95 protein translation via the Akt/mTOR signaling cascade (Akama and McEwen, 2003). However, G1 did not increase phosphorylated Akt, suggesting that GPER1 activation uses a different pathway to regulate PSD-95 expression.

\section{GPER1 interacts with the spine scaffolding protein SAP97}

GPER1 was able to interact with SAP97, a spine scaffolding protein that has been shown to interact with other neuronal G-protein coupled receptors by a PDZ-specific mechanism (Bockaert et al., 2004). PDZ containing scaffolding proteins such as PSD-95 and SAP97 traffic protein complexes that include GPCRs to specific subcellular compartments, such as the dendritic spine (Ranganathan and Ross, 1997; Kim and Sheng, 2004; Romero et al., 2011). Unlike PSD-95, which can be found within the PSD at the center of the spine head, SAP97 differentially localizes to the spine periphery (DeGiorgis et al., 2006) and is associated with endocytic receptor recycling within the dendritic spine compartment (Magalhaes et al., 2012). We have previously demonstrated that GPER1 interacts with PSD-95 in vitro and in vivo in rats (Akama et al., 2013). The interaction between GPER1 and SAP97 further substantiates the GPER1-IR we observed in dendritic spines in the mouse hippocampus and it would position GPER1 for nongenomic signaling at the spine synapse.

If GPER1 also interacts with SAP97 by a PDZ-specific mechanism, then it is possible that GPER1 interacts with other PDZ domain-containing proteins such as PDZ-Rho guanine nucleotide exchange factor (GEF), as multiple GPCR interacting proteins (GIPs) can compete for a GPCR interaction (Bockaert et al., 2004). PDZ-RhoGEF is one of four Rho-specific GEFs (Fukuhara et al., 1999), and in the murine hippocampus, PDZ-RhoGEF immunoreactivity is almost exclusively detected in the stratum radiatum and not in the pyramidal cell somata (Kuner et al., 2002). RhoGEFs, such as PDZ-RhoGEF, are GIPs that couple GPCRs directly to actin-dependent alterations in cellular morphology via RhoA GTPase activity (Ying et al., 2006; Siehler, 2009), and RhoA activation is an initial step in the estrogenstimulated LIMK-cofilin pathway which alters actin polymerization and dendritic spine morphology (Meng et al., 2003; Kramár et al., 2009). We have previously demonstrated that estradiol alters phosphorylated LIMK immunoreactivity in the CA1 stratum radiatum (Yildirim et al., 2008), which would suggest that a PDZ-RhoGEF interaction with GPER1 could facilitate a nongenomic estrogenic action on dendritic spine shape. Therefore, the interaction between GPER1 and SAP97 might not only mediate estradiol-induced alterations in PSD-95 and explain the 
lack of G1 mediated AKT phosphorylation. These findings also might identify future studies to address how estrogens, such as neurosteroids, alter dendritic spine morphology in the hippocampus (Fester et al., 2011).

\section{Conclusion}

Extranuclear expression of GPER1 is abundant in the dorsal mouse hippocampus such that it is well placed to regulate local spine synapse dynamics, neurite growth, and glial cell function. GPER 1 location is strikingly similar to that of $\mathrm{ER} \alpha$ and $\mathrm{ER} \beta$ in the rat and mouse and its activation regulates PSD-95 similar to ERs, suggesting that these receptors have a synergistic role in the maintenance of hippocampal function. Although GPER1 was regulated by estrogen levels in females, it remains to be seen whether changes in the ratio or levels will occur with increasing age and/or time without circulating estrogens as occurs with to $\operatorname{ER} \alpha$ and $\mathrm{ER} \beta$.

\section{References}

Akama KT, McEwen BS (2003) Estrogen stimulates PSD-95 rapid protein synthesis via the Akt/PKB pathway. J Neurosci 23:2333-2339. Medline

Akama KT, Thompson LI, Milner TA, McEwen BS (2013) Post-synaptic density-95 (PSD-95) binding capacity of G-protein-coupled receptor 30 (GPR30), an estrogen receptor that can be identified in hippocampal dendritic spines. J Biol Chem 288:6438-6450. CrossRef Medline

Arias C, Zepeda A, Hernández-Ortega K, Leal-Galicia P, Lojero C, CamachoArroyo I (2009) Sex and estrous cycle-dependent differences in glial fibrillary acidic protein immunoreactivity in the adult rat hippocampus. Horm Behav 55:257-263. CrossRef Medline

Asaki C, Usuda N, Nakazawa A, Kametani K, Suzuki T (2003) Localization of translational components at the ultramicroscopic level at postsynaptic sites of the rat brain. Brain Res 972:168-176. CrossRef Medline

Bence M, Arbuckle MI, Dickson KS, Grant SG (2005) Analyses of murine postsynaptic density-95 identify novel isoforms and potential translational control elements. Brain Res Mol Brain Res 133:143-152. CrossRef Medline

Bockaert J, Fagni L, Dumuis A, Marin P (2004) GPCR interacting proteins (GIP). Pharmacol Ther 103:203-221. CrossRef Medline

Bourque M, Morissette M, Côté M, Soulet D, Di Paolo T (2013) Implication of GPER1 in neuroprotection in a mouse model of Parkinson's disease. Neurobiol Aging 34:887-901. CrossRef Medline

Brake WG, Alves SE, Dunlop JC, Lee SJ, Bulloch K, Allen PB, Greengard P, McEwen BS (2001) Novel target sites for estrogen action in the dorsal hippocampus: an examination of synaptic proteins. Endocrinology 142: 1284-1289. CrossRef Medline

Bulenger S, Marullo S, Bouvier M (2005) Emerging role of homo- and heterodimerization in G-protein-coupled receptor biosynthesis and maturation. Trends Pharmacol Sci 26:131-137. CrossRef Medline

Cosker KE, Courchesne SL, Segal RA (2008) Action in the axon: generation and transport of signaling endosomes. Curr Opin Neurobiol 18:270-275. CrossRef Medline

DeGiorgis JA, Galbraith JA, Dosemeci A, Chen X, Reese TS (2006) Distribution of the scaffolding proteins PSD-95, PSD-93, and SAP97 in isolated PSDs. Brain Cell Biol 35:239-250. CrossRef Medline

Dorsam RT, Gutkind JS (2007) G-protein-coupled receptors and cancer. Nat Rev Cancer 7:79-94. CrossRef Medline

Eagleson KL, Milner TA, Xie Z, Levitt P (2013) Synaptic and extrasynaptic location of the receptor tyrosine kinase met during postnatal development in the mouse neocortex and hippocampus. J Comp Neurol 521: 3241-3259. CrossRef Medline

Fester L, Prange-Kiel J, Jarry H, Rune GM (2011) Estrogen synthesis in the hippocampus. Cell Tissue Res 345:285-294. CrossRef Medline

Filardo EJ, Quinn JA, Bland KI, Frackelton AR Jr (2000) Estrogen-induced activation of Erk-1 and Erk-2 requires the G-protein-coupled receptor homolog, GPR30, and occurs via trans-activation of the epidermal growth factor receptor through release of HB-EGF. Mol Endocrinol 14: 1649-1660. CrossRef Medline

Ford J, Hajibeigi A, Long M, Hahner L, Gore C, Hsieh JT, Clegg D, Zerwekh J, Oz OK (2011) GPR30 deficiency causes increased bone mass, miner- alization, and growth plate proliferative activity in male mice. J Bone Miner Res 26:298-307. CrossRef Medline

Fukuhara S, Murga C, Zohar M, Igishi T, Gutkind JS (1999) A novel PDZ domain containing guanine nucleotide exchange factor links heterotrimeric $G$ proteins to rho. J Biol Chem 274:5868-5879. CrossRef Medline

Gazzaley A, Kay S, Benson DL (2002) Dendritic spine plasticity in hippocampus. Neuroscience 111:853-862. CrossRef Medline

González-Burgos I, Alejandre-Gómez M, Cervantes M (2005) Spine-type densities of hippocampal CA1 neurons vary in proestrus and estrus rats. Neurosci Lett 379:52-54. CrossRef Medline

Hammes SR, Levin ER (2007) Extranuclear steroid receptors: nature and actions. Endocr Rev 28:726-741. CrossRef Medline

Hammond R, Gibbs RB (2011) GPR30 is positioned to mediate estrogen effects on basal forebrain cholinergic neurons and cognitive performance. Brain Res 1379:53-60. CrossRef Medline

Hammond R, Nelson D, Gibbs RB (2011) GPR30 co-localizes with cholinergic neurons in the basal forebrain and enhances potassium-stimulated acetylcholine release in the hippocampus. Psychoneuroendocrinology 36: 182-192. CrossRef Medline

Hammond R, Nelson D, Kline E, Gibbs RB (2012) Chronic treatment with a GPR30 antagonist impairs acquisition of a spatial learning task in young female rats. Horm Behav 62:367-374. CrossRef Medline

Hof PR, Young WG, Bloom FE, Belichenko PV, Celio MR (2000) Comparative cytoarchitectonic atlas of the C57BL/6 and 129/SV mouse brains. Amsterdam: Elsevier.

Kelly MJ, Levin ER (2001) Rapid actions of plasma membrane estrogen receptors. Trends Endocrinol Metab 12:152-156. CrossRef Medline

Kim E, Sheng M (2004) PDZ domain proteins of synapses. Nat Rev Neurosci 5:771-781. CrossRef Medline

Kindler S, Kreienkamp HJ (2012) Dendritic mRNA targeting and translation. Adv Exp Med Biol 970:285-305. CrossRef Medline

Klintsova A, Levy WB, Desmond NL (1995) Astrocytic volume fluctuates in the hippocampal CA1 region across the estrous cycle. Brain Res 690:269274. CrossRef Medline

Kornau HC, Schenker LT, Kennedy MB, Seeburg PH (1995) Domain interaction between NMDA receptor subunits and the postsynaptic density protein PSD-95. Science 269:1737-1740. CrossRef Medline

Kosaka Y, Quillinan N, Bond C, Traystman R, Hurn P, Herson P (2012) GPER1/GPR30 activation improves neuronal survival following global cerebral ischemia induced by cardiac arrest in mice. Transl Stroke Res 3:500-507. CrossRef Medline

Kramár EA, Chen LY, Brandon NJ, Rex CS, Liu F, Gall CM, Lynch G (2009) Cytoskeletal changes underlie estrogen's acute effects on synaptic transmission and plasticity. J Neurosci 29:12982-12993. CrossRef Medline

Kuner R, Swiercz JM, Zywietz A, Tappe A, Offermanns S (2002) Characterization of the expression of PDZ-RhoGEF, LARG and G(alpha)12/G(alpha)13 proteins in the murine nervous system. Eur J Neurosci 16:2333-2341. CrossRef Medline

Lamprecht MR, Morrison B 3rd (2014) GPR30 activation is neither necessary nor sufficient for acute neuroprotection by 17 beta-estradiol after an ischemic injury in organotypic hippocampal slice cultures. Brain Res 1563:131-137. CrossRef Medline

Lee SJ, Romeo RD, Svenningsson P, Campomanes CR, Allen PB, Greengard P, McEwen BS (2004) Estradiol affects spinophilin protein differently in gonadectomized males and females. Neuroscience 127:983-988. CrossRef Medline

Li C, Brake WG, Romeo RD, Dunlop JC, Gordon M, Buzescu R, Magarinos AM, Allen PB, Greengard P, Luine V, McEwen BS (2004) Estrogen alters hippocampal dendritic spine shape and enhances synaptic protein immunoreactivity and spatial memory in female mice. Proc Natl Acad Sci U S A 101:2185-2190. CrossRef Medline

Li N, Lee B, Liu RJ, Banasr M, Dwyer JM, Iwata M, Li XY, Aghajanian G, Duman RS (2010) mTOR-dependent synapse formation underlies the rapid antidepressant effects of NMDA antagonists. Science 329:959-964. CrossRef Medline

Liu SB, Zhao MG (2013) Neuroprotective effect of estrogen: role of nonsynaptic NR2B-containing NMDA receptors. Brain Res Bull 93:27-31. CrossRef Medline

Liu-Yesucevitz L, Bassell GJ, Gitler AD, Hart AC, Klann E, Richter JD, Warren ST, Wolozin B (2011) Local RNA translation at the synapse and in disease. J Neurosci 31:16086-16093. CrossRef Medline

Magalhaes AC, Dunn H, Ferguson SS (2012) Regulation of GPCR activity, 
trafficking and localization by GPCR-interacting proteins. Br J Pharmacol 165:1717-1736. CrossRef Medline

Maggiolini M, Vivacqua A, Fasanella G, Recchia AG, Sisci D, Pezzi V, Montanaro D, Musti AM, Picard D, Andò S (2004) The G protein-coupled receptor GPR30 mediates c-fos up-regulation by 17beta-estradiol and phytoestrogens in breast cancer cells. J Biol Chem 279:27008-27016. CrossRef Medline

McEwen BS, Milner TA (2007) Hippocampal formation: shedding light on the influence of sex and stress on the brain. Brain Res Rev 55:343-355. CrossRef Medline

Meng Y, Zhang Y, Tregoubov V, Falls DL, Jia Z (2003) Regulation of spine morphology and synaptic function by LIMK and the actin cytoskeleton. Rev Neurosci 14:233-240. Medline

Milner TA, Bacon CE (1989) Ultrastructural localization of tyrosine hydroxylase-like immunoreactivity in the rat hippocampal formation. J Comp Neurol 281:479-495. CrossRef Medline

Milner TA, McEwen BS, Hayashi S, Li CJ, Reagan LP, Alves SE (2001) Ultrastructural evidence that hippocampal alpha estrogen receptors are located at extranuclear sites. J Comp Neurol 429:355-371. CrossRef Medline

Milner TA, Ayoola K, Drake CT, Herrick SP, Tabori NE, McEwen BS, Warrier S, Alves SE (2005) Ultrastructural localization of estrogen receptor beta immunoreactivity in the rat hippocampal formation. J Comp Neurol 491:81-95. CrossRef Medline

Milner TA, Waters EM, Robinson DC, Pierce JP (2011) Degenerating processes identified by electron microscpic immunocytochemical methods. In: Neurodegeneration, methods and protocols (Manfredi G, Kawamata H, eds), pp 23-59. New York: Springer.

Mitterling KL, Spencer JL, Dziedzic N, Shenoy S, McCarthy K, Waters EM, McEwen BS, Milner TA (2010) Cellular and subcellular localization of estrogen and progestin receptor immunoreactivities in the mouse hippocampus. J Comp Neurol 518:2729-2743. CrossRef Medline

Musnier A, Blanchot B, Reiter E, Crépieux P (2010) GPCR signalling to the translation machinery. Cell Signal 22:707-716. CrossRef Medline

Nakamura NH, McEwen BS (2005) Changes in interneuronal phenotypes regulated by estradiol in the adult rat hippocampus: a potential role for neuropeptide Y. Neuroscience 136:357-369. CrossRef Medline

Peters A, Palay SL, Webster Hd (1991) The fine structure of the nervous system, Ed 3. New York: Oxford UP.

Pierce JP, Kurucz OS, Milner TA (1999) The morphometry of a peptidergic transmitter system before and after seizure: I. Dynorphin B-like immunoreactivity in the hippocampal mossy fiber system. Hippocampus 9:255-276. CrossRef Medline

Pierce JP, Kelter DT, McEwen BS, Waters EM, Milner TA (2014) Hippocampal mossy fiber leu-enkephalin immunoreactivity in female rats is significantly altered following both acute and chronic stress. J Chem Neuroanat 55:9-17. CrossRef Medline

Prossnitz ER, Arterburn JB, Smith HO, Oprea TI, Sklar LA, Hathaway HJ (2008) Estrogen signaling through the transmembrane G proteincoupled receptor GPR30. Annu Rev Physiol 70:165-190. CrossRef Medline

Ranganathan R, Ross EM (1997) PDZ domain proteins: scaffolds for signaling complexes. Curr Biol 7:R770-R773. CrossRef Medline

Razandi M, Pedram A, Greene GL, Levin ER (1999) Cell membrane and nuclear estrogen receptors (ERs) originate from a single transcript: studies of ERa and ERb expressed in Chinese hamster ovary cells. Mol Endocrinol 13:307-319. CrossRef Medline

Revankar CM, Cimino DF, Sklar LA, Arterburn JB, Prossnitz ER (2005) A transmembrane intracellular estrogen receptor mediates rapid cell signaling. Science 307:1625-1630. CrossRef Medline

Rivero-Müller A, Chou YY, Ji I, Lajic S, Hanyaloglu AC, Jonas K, Rahman N, Ji TH, Huhtaniemi I (2010) Rescue of defective G protein-coupled receptor function in vivo by intermolecular cooperation. Proc Natl Acad Sci U S A 107:2319-2324. CrossRef Medline

Romeo RD, McCarthy JB, Wang A, Milner TA, McEwen BS (2005) Sex differences in hippocampal estradiol-induced N-methyl-D-aspartic acid binding and ultrastructural localization of estrogen receptor alpha. Neuroendocrinology 81:391-399. CrossRef Medline

Romero G, von Zastrow M, Friedman PA (2011) Role of PDZ proteins in regulating trafficking, signaling, and function of GPCRs: means, motif, and opportunity. Adv Pharmacol 62:279-314. CrossRef Medline
Rozengurt E (2007) Mitogenic signaling pathways induced by G proteincoupled receptors. J Cell Physiol 213:589-602. CrossRef Medline

Siehler S (2009) Regulation of RhoGEF proteins by G12/13-coupled receptors. Br J Pharmacol 158:41-49. CrossRef Medline

Smith CC, McMahon LL (2006) Estradiol-induced increase in the magnitude of long-term potentiation is prevented by blocking NR2Bcontaining receptors. J Neurosci 26:8517-8522. CrossRef Medline

Snyder MA, Cooke BM, Woolley CS (2011) Estradiol potentiation of NR2B-dependent EPSCs is not due to changes in NR2B protein expression or phosphorylation. Hippocampus 21:398-408. CrossRef Medline

Sortino MA, Chisari M, Merlo S, Vancheri C, Caruso M, Nicoletti F, Canonico PL, Copani A (2004) Glia mediates the neuroprotective action of estradiol on beta-amyloid-induced neuronal death. Endocrinology 145: 5080-5086. CrossRef Medline

Spencer JL, Waters EM, Milner TA, McEwen BS (2008a) Estrous cycle regulates activation of hippocampal Akt, LIM kinase, and neurotrophin receptors in C57BL/6 mice. Neuroscience 155:1106-1119. CrossRef Medline

Spencer JL, Waters EM, Romeo RD, Wood GE, Milner TA, McEwen BS (2008b) Uncovering the mechanisms of estrogen effects on hippocampal function. Front Neuroendocrinol 29:219-237. CrossRef Medline

Spencer JL, Waters EM, Milner TA, Lee FS, McEwen BS (2010) BDNF variant Val66Met interacts with estrous cycle in the control of hippocampal function. Proc Natl Acad Sci U S A 107:4395-4400. CrossRef Medline

Spencer-Segal JL, Waters EM, Bath KG, Chao MV, McEwen BS, Milner TA (2011) Distribution of phosphorylated TrkB receptor in the mouse hippocampal formation depends on sex and estrous cycle stage. J Neurosci 31:6780-6790. CrossRef Medline

Spencer-Segal JL, Tsuda MC, Mattei L, Waters EM, Romeo RD, Milner TA, McEwen BS, Ogawa S (2012) Estradiol acts via estrogen receptors alpha and beta on pathways important for synaptic plasticity in the mouse hippocampal formation. Neuroscience 202:131-146. CrossRef Medline

Tang H, Zhang Q, Yang L, Dong Y, Khan M, Yang F, Brann DW, Wang R (2014) GPR30 mediates estrogen rapid signaling and neuroprotection. Mol Cell Endocrinol 387:52-58. CrossRef Medline

Thomas P, Pang Y, Filardo EJ, Dong J (2005) Identity of an estrogen membrane receptor coupled to a $G$ protein in human breast cancer cells. Endocrinology 146:624-632. CrossRef Medline

Tian Z, Wang Y, Zhang N, Guo YY, Feng B, Liu SB, Zhao MG (2013) Estrogen receptor GPR30 exerts anxiolytic effects by maintaining the balance between GABAergic and glutamatergic transmission in the basolateral amygdala of ovariectomized mice after stress. Psychoneuroendocrinology 38:2218-2233. CrossRef Medline

Torres-Reveron A, Khalid S, Drake CT, Milner TA (2006) Enkephalin and dynorphin immunoreactivities increase in the dorsal hippocampus in response to estrogens and colocalize with estrogen receptor beta in mossy fiber terminals. Program No. 724.6, pp 724.6/D4. Neuroscience Meeting Planner, Atlanta, GA: Society for Neuroscience.

Torres-Reveron A, Khalid S, Williams TJ, Waters EM, Drake CT, McEwen BS, Milner TA (2008) Ovarian steroids modulate leu-enkephalin levels and target leu-enkephalinergic profiles in the female hippocampal mossy fiber pathway. Brain Res 1232:70-84:70-84. CrossRef Medline

Torres-Reveron A, Khalid S, Williams TJ, Waters EM, Jacome L, Luine VN, Drake CT, McEwen BS, Milner TA (2009) Hippocampal dynorphin immunoreactivity increases in response to gonadal steroids and is positioned for direct modulation by ovarian steroid receptors. Neuroscience 159:204-216. CrossRef Medline

Turner CD, Bagnara JT (1971) General endocrinology. Philadelphia: WB Saunders.

Verpelli C, Schmeisser MJ, Sala C, Boeckers TM (2012) Scaffold proteins at the postsynaptic density. Adv Exp Med Biol 970:29-61. CrossRef Medline

Wang C, Dehghani B, Magrisso IJ, Rick EA, Bonhomme E, Cody DB, Elenich LA, Subramanian S, Murphy SJ, Kelly MJ, Rosenbaum JS, Vandenbark AA, Offner H (2008) GPR30 contributes to estrogen-induced thymic atrophy. Mol Endocrinol 22:636-648. CrossRef Medline

Waters EM, Torres-Reveron A, McEwen BS, Milner TA (2008) Ultrastructural localization of extranuclear progestin receptors in the rat hippocampal formation. J Comp Neurol 511:34-46. CrossRef Medline

Waters EM, Mitterling K, Spencer JL, Mazid S, McEwen BS, Milner TA (2009) Estrogen receptor alpha and beta specific agonists regulate ex- 
pression of synaptic proteins in rat hippocampus. Brain Res 1290:1-11. CrossRef Medline

Weiland NG, Orikasa C, Hayashi S, McEwen BS (1997) Distribution and hormone regulation of estrogen receptor immunoreactive cells in the hippocampus of male and female rats. J Comp Neurol 388:603-612. CrossRef Medline

Woolley CS (1998) Estrogen-mediated structural and functional synaptic plasticity in the female rat hippocampus. Horm Behav 34:140-148. CrossRef Medline

Woolley CS, McEwen BS (1993) Roles of estradiol and progesterone in regulation of hippocampal dendritic spine density during the estrous cycle in the rat. J Comp Neurol 336:293-306. CrossRef Medline

Woolley CS, McEwen BS (1994) Estradiol regulates hippocampal dendritic spine density via an $\mathrm{N}$-methyl-D-aspartate receptor-dependent mechanism. J Neurosci 14:7680-7687. Medline

Woolley CS, Wenzel HJ, Schwartzkroin PA (1996) Estradiol increases the frequency of multiple synapse boutons in the hippocampal CA1 region of the adult female rat. J Comp Neurol 373:108-117. CrossRef Medline

Woolley CS, Weiland NG, McEwen BS, Schwartzkroin PA (1997) Estradiol increases the sensitivity of hippocampal CA1 pyramidal cells to NMDA receptor-mediated synaptic input: correlation with dendritic spine density. J Neurosci 17:1848-1859. Medline
Xu X, Zhang Z (2006) Effects of estradiol benzoate on learning-memory behavior and synaptic structure in ovariectomized mice. Life Sci 79:15531560. CrossRef Medline

Yildirim M, Janssen WG, Tabori NE, Adams MM, Yuen GS, Akama KT, McEwen BS, Milner TA, Morrison JH (2008) Estrogen and aging affect synaptic distribution of phosphorylated LIM kinase (pLIMK) in CA1 region of female rat hippocampus. Neuroscience 152:360-370. CrossRef Medline

Ying Z, Jin L, Palmer T, Webb RC (2006) Angiotensin II up-regulates the leukemia-associated Rho guanine nucleotide exchange factor (RhoGEF), a regulator of $\mathrm{G}$ protein signaling domain-containing RhoGEF, in vascular smooth muscle cells. Mol Pharmacol 69:932-940. CrossRef Medline

Yuste R, Bonhoeffer T (2004) Genesis of dendritic spines: insights from ultrastructural and imaging studies. Nat Rev Neurosci 5:24-34. CrossRef Medline

Zheng H, Loh HH, Law PY (2013) Posttranslation modification of G protein-coupled receptor in relationship to biased agonism. Methods Enzymol 522:391-408. CrossRef Medline

Znamensky V, Akama KT, McEwen BS, Milner TA (2003) Estrogen levels regulate the subcellular distribution of phosphorylated Akt in hippocampal CA1 dendrites. J Neurosci 23:2340-2347. Medline 